\title{
NON-RECOGNITION OF MUSLIM MARRIAGES: DISCRIMINATION AND SOCIAL INJUSTICE
}

\author{
Razaana Denson \\ BA LLB HDE LLM \\ Advocate of the High Court \\ Lecturer in Private Law \\ Nelson Mandela Metropolitan University \\ Port Elizabeth
}

\section{SUMMARY}

The following issues are discussed in the article, namely the legal status of Muslim marriages, the legal nature of Muslim marriages, the reasons for non-recognition, in particular the concept of "public policy", as well as the various approaches adopted by the South African courts when dealing with the issue whether Muslim marriages should be granted legal recognition. The effect of the Constitution of the Republic of South Africa, 1996 on the status and consequences of Muslim marriages as well as the proposal for legal reform in the form of a draft Muslim Marriages Bill which was released on the 22 July 2003 is also dealt with.

INTRODUCTION

South Africa is a country rich in cultural diversity. Despite this cultural diversity, the recognition of systems of religious, personal or family law for certain cultural and religious groups has either been limited or virtually nonexistent. The position in South Africa at present is that, in terms of a civil marriage, the spouses may not during the subsistence of such marriage enter into another marriage. ${ }^{1}$ The question that arises is whether the nonrecognition of Muslim marriages performed in accordance with religious rites, can be regarded as unconstitutional.

To address this question, the following issues will be discussed: firstly, the legal status of Muslim marriages, as well as the reasons for non-recognition of such marriages. Secondly, the fundamental rights entrenched in the Constitution of the Republic of South Africa, 1996, will be considered to determine whether the non-recognition of Muslim marriages is constitutional or not. Various cases that deal with marriages entered into in terms of

This is in accordance with the definition of marriage as provided by various academic writers such as Sinclair assisted by Heaton The Law of Marriage Vol 1 (1996) 305; and Cronje and Heaton South African Family Law (2000) 21. 
Islamic law will be discussed to demonstrate the approaches adopted by the courts. Lastly, proposals for legal reform will also be considered.

\section{LEGAL STATUS OF MUSLIM MARRIAGES}

From the definition of marriage being "the voluntary union for life in common of one man and one woman to the exclusion of all others while it lasts", ${ }^{2}$ it can be deduced that only voluntary unions which are monogamous in nature, have historically been recognized in terms of South African law because they possess the element of exclusiveness. A marriage that did not meet the requirements as set out in terms of the civil law, was therefore regarded as invalid. From its inception Muslim marriages have allowed for the plurality of spouses, which has led to strong opposition from certain sectors of the Western world which refused to recognize these unions. In South Africa, Muslim marriages, according to Islamic rites, are viewed as contra bonos mores because of their polygamous nature. ${ }^{3}$ Non-recognition of Muslim marriages has also meant that any consequences flowing from such marriage could not be enforced. ${ }^{4}$ Despite the fact that the parties to a potentially polygamous union may regard themselves as married, there is no legal connection between them. ${ }^{5}$ Examples of the important effect of the non-recognition of Muslim unions can be listed as follows: ${ }^{6}$

- there is no joint estate and any nuptial agreement is void;

- there are no financial obligations between the spouses inter se and no claim for loss of support accrues to the dependant spouse on the death of the other spouse;

- the wife enjoys no claim for maintenance on divorce or against her husband's deceased estate;

\section{Sinclair 305}

Ismail v Ismail 19831 SA 1006 (A) 1025C, where it was held that the "claims are based on custom or contract which arises directly from, and is intimately connected with, the polygamous relationship entered into by the parties ... it follows from this that, if the polygamous relationship is regarded as void on the grounds of public policy, the custom or the contract is also vitiated". However, mention must be made of the fact that South African law is not consistent in this regard. Firstly, African customary marriages, even if actually polygamous, are accorded legislative recognition in terms of the Recognition of Customary Marriages Act 120 of 1998. Secondly, despite being void, polygamous Muslim unions have certain legal consequences attached to them, for example, such marriages are recognized for the purposes of insolvency as section 21(3) of the Insolvency Act 24 of 1936, describes the word "spouse" to include a wife or husband married "according to any law or custom".

4 Maithufi "Possible Recognition of Polygamous Marriages: Ryland v Edros 19972 SA 690 (C)" 1997 THRHR 695.

5 The consequences of non-recognition are very serious indeed, particularly for the wife of such a union.

6 Cachalia "Citizenship, Muslim Family Law and a Future South African Constitution: A Preliminary Enquiry" 1993 THRHR 392.

7 See par 41 for a discussion of the Amod case where it was held that the contractual duty of support which a husband owes his wife in terms of their Islamic marriage, satisfied the requirements of the dependant's action for loss of support against a third party. 
- the law of intestate succession does not apply to the parties of such unions which means that the wife, for example, would effectively be disinherited if her husband dies intestate ${ }^{8}$;

- both parties to such a union can be compelled to give evidence against each other in criminal proceedings.

Despite the fact that Muslim marriages are not granted recognition in terms of South African law, Muslims continue to regulate their domestic affairs according to Islamic law in that they are married by a representative of the Muslim clergy who performs marriage in a mosque. If a breakdown of a marriage occurs, such marriage is effectively dissolved by the talaq (repudiation) procedure. A brief discussion of the marriage ceremony, the marital rights and duties, and divorce procedure under Islamic law now becomes necessary. It will become apparent that Islamic law does not distinguish between legal principles and religious principles.

\section{3}

\section{LEGAL NATURE OF A MUSLIM MARRIAGE ${ }^{9}$}

\section{The wedding ceremony}

A betrothal (Khitba), which precedes a marriage contract, is essentially composed of approaches made by the man (or his family), to the woman (or her family), asking for her hand in marriage if the proposed union is legally possible. ${ }^{10}$ Terms and conditions are negotiated at this stage, which may end in mutual promises of marriage. Although highly recommended the "khitba" is not an obligatory step to render the marriage valid. The word "betrothal" is used in preference to engagement as it is a more conventional arrangement and, unlike the latter, does not per se entail damage on the breach thereof. Both parties should be aware of the circumstances of the other and should know the other's character and behaviour in order for betrothal to be valid. ${ }^{11}$ If the woman, or those representing her, accepts the man's offer of marriage, the betrothal takes place and as such it constitutes a reciprocated promise by the two parties to marry at some time in the future. After the conclusion of such betrothal, other men are precluded from proposing to the same woman, if it is known that the woman has already been betrothed. The betrothal merely constitutes a mutual promise of marriage between the parties and does not constitute a marriage contract. The betrothal is also not legally binding between the parties in that it does not give rise to an action for breach of promise to marry.

8 See par 41 below for a discussion of the latest cases involving intestate succession with regard to a monogamous Muslim marriage, as well as a polygamous Muslim marriage.

9 Mention must be made of the fact that in terms of Islamic Jurisprudence there are four Sunni schools of thought, namely Shafi'i, Hanafi, Maliki and Hanbali. The author has elected to expound the view of the Shafi'i school of thought.

10 Bainham The International Survey of Family Law (1994) 3.

11 Nasir The Status of Women Under Islamic Law and Under Modern Islamic Legislation (1994) 4 
As in any other contract, a marriage contract (aqd-un-nikah) can only be concluded through the two essentialia or pillars (arkan) of offer and acceptance by the two principals or their proxies. ${ }^{12}$ There must be a meeting of the minds in respect of the offer and acceptance. Both parties to the proposed marriage must possess legal capacity in order for the marriage to be valid. Over and above compliance with the provisions regarding offer and acceptance and legal capacity, there are also other requirements which have to be met for the marriage to be regarded as valid in terms of Islamic law (Shari'ah). ${ }^{13}$ The other requirements are the following: Firstly, the presence of two males or one male and two females at the wedding ceremony to act as witnesses to such ceremony. If both parties to the marriage are Muslim, then it is required for the witnesses to be Muslim as well. Secondly, the female partner to a proposed marriage must immediately be eligible for marriage to the person who proposed. ${ }^{14}$ The third condition is that the marriage contract shall have immediate effect, and shall not be suspended or deferred to the future. ${ }^{15}$ The marriage contract may include conditions, for example, that the woman shall retain the right to dissolve the marriage and that the husband may not marry a second wife during the subsistence of the first marriage. ${ }^{16}$

The marriage ceremony is performed by a religious scholar, that is, a person who teaches the faithful about the Qur'an, and leads them through their prayers in a Mosque. The marriage ceremony can take place either in a gathering of men with neither the bride nor any other women being present, ${ }^{17}$ or alternatively it can take place in the presence of the bride in which case she would give consent without her guardian announcing it on her behalf. The religious scholar is also allowed to approach the bride himself, and obtain the necessary consent from her; this being done in the presence of two formal witnesses. According to Muslim custom, the person who performs the marriage ceremony is not required to be a marriage officer in terms of the Marriage Act 25 of 1961.

In terms of the teachings of the Qur'an, a husband is allowed to have a maximum of four wives simultaneously, provided he is able and willing to treat such wives on a basis of absolute equality as far as their material needs are concerned. It is this plurality of spouses which is the fundamental cause for the incompatibility between public policy, the Marriage Act 25 of 1961 , and Muslim marriages according to the tenets of Islamic law.

12 Bekker, Rautenbach and Goolam Introduction to Legal Pluralism in South Africa Part II Religious Legal Systems (2006) 253.

13 Ibid.

14 In other words, the female partner must not be in the position where she is married but separated from her husband but no talaq (repudiation) of her marriage has yet occurred, nor must she be a widow who is still in her mourning period of four months and ten days (iddah) after her husband's death.

15 Nasir (1994) 5.

16 Bekker, Rautenbach and Goolam 253.

17 In this instance the bride's consent is still required, but her guardian would give consent on her behalf. 


\section{Marital rights and duties}

When two Muslims enter into a contract of marriage, certain rights and duties arise between the two spouses. ${ }^{18}$ These can be summarized as follows:

\section{Property Rights}

As spouses to an Islamic marriage maintain separate estates, community of property is not recognized under Islamic law. Each spouse retains sole ownership and control of his or her property, whether movable or immovable, and whether acquired before or after the marriage. ${ }^{19}$ Under Islamic law the woman enjoys the absolute right to earn, acquire and inherit property. She also possesses the right of ownership over her goods and wealth independent of any male. ${ }^{20}$ She is entitled to instruct any person of her choice to deal with her property without consulting with her husband. ${ }^{21}$ Therefore, it is clear that the woman does not forego any of her property rights by reason of marriage.

\section{Dower}

The payment of a dower (mahr) is an indispensable component of an Islamic marriage contract. It incorporates either a sum of money or property which becomes payable by the husband to the wife after the prospective spouses agreed to conclude the marriage ceremony. ${ }^{22}$ The reason for payment of dowry is to safeguard the woman's economic or financial position after the marriage takes place as she is not obligated to inform, nor consult, her husband as to how the dowry will be used. ${ }^{23}$ The dowry becomes the sole property of the bride. The sum or value of the dower is not prescribed by law, rather it may be agreed upon by the parties, or it may be determined via the operation of Islamic law, with due regard to the social status of the parties. The payment of the dower can be effected in one of three ways, namely: ${ }^{24}$

(i) the transfer of the dower to the wife immediately on the conclusion of the marriage; or

(ii) the payment of the dower may be deferred to a later date; or

\footnotetext{
18 As is the case with a civil marriage concluded in terms of the Marriage Act 25 of 1961.

19 Bekker, Rautenbach and Goolam 255.

20 Bulbalia "Women's Rights and Marital Status: Are We Moving Closer to Islamic Law?" 1983 De Rebus 430431.

21 Roodt "Marriages Under Islamic Law and Patrimonial Consequences and Financial Relief" 1995 Codicillus 5051.

22 Nasir (1994) 43

23 Esposito Women in Muslim Family Law (1982) 24.

24 Bekker,Rautenbach and Goolam 255.
} 
(iii) the payment of a portion of the dower at the conclusion of the marriage, the balance to be paid if and when the marriage is dissolved by divorce or death of the husband.

The right to dower is an inalienable right of the wife in that it is taken for granted even if it is not expressly stated in the marriage contract. In addition, the wife would not lose her right to payment of a dower through prescription alone. ${ }^{25}$

\section{Maintenance}

Maintenance (nafaqah) is primarily the husband's duty, regardless of the private means of the wife. The wife is under no obligation to contribute financially towards the running of the household and where she does, she may claim such amounts from her husband. ${ }^{26}$ The wife has the right to be provided for at the expense of the husband, on a scale suitable to his means, with food, clothing and housing. Where the marriage is dissolved, the husband is under an obligation to lodge and maintain the wife during the three-month waiting period (iddah). Once the three-month waiting period has elapsed, the husband is not obliged to pay maintenance to his former wife. ${ }^{27}$

\section{Spousal Duties}

Both spouses are obliged to be faithful and chaste and both spouses have an obligation to refrain from extra-marital relationships. Failure to observe this constitutes adultery and justifies divorce. Included in the duties of the wife is the supervision of the family home, as well as the improvement and protection of the family relationships. ${ }^{28}$ The marital rights and duties of the spouses arising from the marriage depend solely on the commitment of the parties towards each other and their obedience to the Qur'an.

\section{Divorce}

Marriage is the cornerstone of every Muslim society and is seen as a permanent institution. Therefore, divorce (talaq) is regarded as the greatest enemy of marriage. Divorce is only permitted when the marriage has broken down irretrievably, and there is no reasonable prospect for the restoration of a normal marriage relationship between the parties through mediation. However, it is also accepted that there is no value in keeping a marriage together when the union has no future. ${ }^{29}$ An Islamic marriage contract is dissolved at the death of a spouse, at the initiative of either the husband or the wife

\footnotetext{
Nasir The Islamic Law of Personal Status (1990) 87.

Bekker, Rautenbach and Goolam 256.

The rule applies unless the wife is pregnant or is breast-feeding, in which case the husband is obliged to maintain the wife until the birth of the child or the completion of breastfeeding.

28 Nasir (1994) 431.

29 Keene Believers in One God: Judaism, Christianity, Islam (1993) 168.
} 
during their lifetime, through mutual agreement or lastly by judicial process. ${ }^{30}$ A brief discussion of each of these methods of divorce will now ensue.

\section{Divorce by the husband}

A divorce initiated by the husband can be effected in one of two ways. Firstly, by means of a divorce according to the rules laid down in the traditions of Muhammad known as the talaq al-sunna. This method of divorce is recommended by Islamic law. The second method is to effect a divorce not in accordance to the rules laid down by prophetic tradition and is known as talaq al-bidia. This method of divorce is not recommended and has long been the subject of much controversy. ${ }^{31}$ Where a divorce does take place, this can be done orally or in writing; where the husband exercises his right of repudiation on three successive occasions, the divorce becomes irrevocable. ${ }^{32}$ Once the divorce becomes irrevocable, the parties are forbidden to remarry each other unless the former wife enters into a marriage with a third party. ${ }^{33}$

\section{Divorce by the wife}

The talaq al-tafwid (delegation divorce) allows the wife trapped in an unhappy marriage to terminate her marriage expeditiously without any court intervention and without having to forego her right to claim the dower in full. ${ }^{34}$ Support for the delegated divorce is found in the following verse of the Qur'an which states: "I will provide for your enjoyment and set you free in a handsome manner.,35

\section{З 33 Divorce by mutual agreement}

Where the husband makes an offer for a mutually agreed divorce, he may not withdraw his offer before the wife has given him an answer. Should the wife accept the offer for a mutually agreed divorce, the divorce is effective immediately. In contrast, if the wife makes the initial offer of a mutually agreed divorce, she is entitled to withdraw the offer at any time prior to acceptance by the husband. ${ }^{36}$

\section{Judicial divorce}

An action for judicial divorce (faskh) can be initiated by either the husband or wife. Faskh is the only method by which a wife can obtain a divorce without

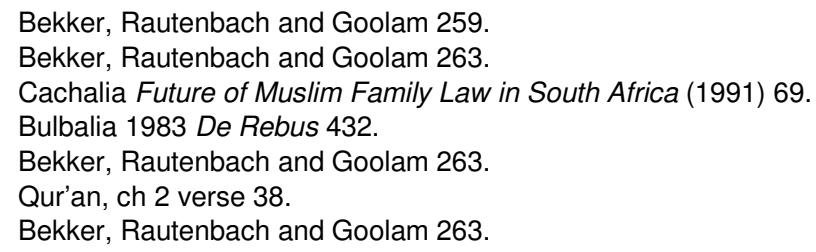


the husband's consent. Where the wife wishes to apply for a faskh, this may be done on one of the following grounds: ${ }^{37}$

- injury or discord;

- failure to maintain;

- defect on the part of the husband; or

- husband's absence sine causa or imprisonment.

Divorces can further be divided into revocable and irrevocable divorces. An irrevocable divorce (ba'in) dissolves the marriage with immediate effect. ${ }^{38}$ A revocable divorce (raj'i) only becomes effective at the end of the waiting period (iddah) that starts after the first "divorce" is pronounced. During the waiting period the woman remains the legal wife of the husband and the husband is as such under an obligation to support his wife financially.

\section{THE NOTION OF "PUBLIC POLICY" IN POLYGAMOUS MARRIAGES}

As indicated previously, the refusal to grant recognition to potentially polygamous unions has always been based on the ground of public policy. It therefore becomes necessary to discuss the concept "public policy" to ascertain whether the notion of "public policy" as adopted by the courts, can still be regarded as the yardstick to measure the validity of marriages in the light of South Africa's democratization and the enactment of the Constitution. ${ }^{39}$

\section{Judicial interpretation of "public policy" in Muslim marriages}

It is difficult to define the concept of public policy in a heterogeneous society. Public policy, its determination and the parameters in which it should operate in a free and democratic society, have always posed a direct threat for marriages entered into according to the tenets of Islamic law. Courts have treated the concept "public policy" with great circumspection, as evidenced by the remarks made in the following two cases. In Kader $v$ Kader $^{40}$ Lewis AJP said that:

"[p]ublic policy is a very unruly horse and once you get astride it you will never know where it will carry you."

37 Moodley "The Islamic Laws of Divorce, Polygamy and Succession" 2001 Codicillus 89.

38 As discussed in par 331 above.

39 Palser "An Evaluation of the Position of Potentially Polygamous Marriages in a Democratic South Africa" 1998 Journal for Juridical Science 85.

$40 \quad 19723$ SA 203 (RA).

41 Kader $v$ Kader supra 209C. 
In Olsen $v$ Standaloft ${ }^{42}$ Baron JA resorted to the conventional methods of finding answers to this problematic concept by asking the following questions:

"Who are the public with whose welfare we are concerned? How does one approach the problems in societies in which there are several ethnic and cultural groups? Where the persons concerned are members of such a group, is the court entitled to have regard to culture and traditions of that group in considering the question of potential harm? Or is the correct approach to consider the potential harm to the socjety as a whole, but taking into account that the society is not homogeneous?

Despite posing these pertinent questions, it is very disappointing to note that Baron JA never provided any answers to the questions in his judgment. Kerr, ${ }^{44}$ in contrast, states that the last two questions posed in the Olsen case should have been answered in the affirmative. The reason is that when potential harm to a society as a whole is considered, due regard should be taken of the culture and traditions of the group in question, and of other groups, if any, with similar traditions.

Before the introduction of the interim Constitution, ${ }^{45}$ the interpretation of public policy in cases like Seedat's Executor $v$ The Master (Natal) ${ }^{46}$ and Ismail $v$ Ismaif ${ }^{47}$ afforded no legitimacy to marriages concluded under Islamic rites.

In Seedat's Executors $v$ The Master (Natal) a potentially polygamous union was defined as follows:

"the nature of which is consistent with the husband marrying another wife during its continuance. Whether he exercises his privilege or not is beside the question. The fact that the man and the woman contract on the basis that he shall be at liberty to do so differentiates their relationship from that to which we give the name of marriage, and stamps their union as polygamous."

In the above case the court further stated that such a union will not be granted recognition as a valid marriage, as "polygamy vitally affects the nature of the most important relationship into which human beings can enter. It is reprobated by the majority of civilised people, on grounds of morality and religion". ${ }^{49}$ In the same case it was stated that anything that is "fundamentally opposed to our principles and institutions is contrary to public policy" ${ }^{\prime \prime 0}$ as is the case with polygamous unions.

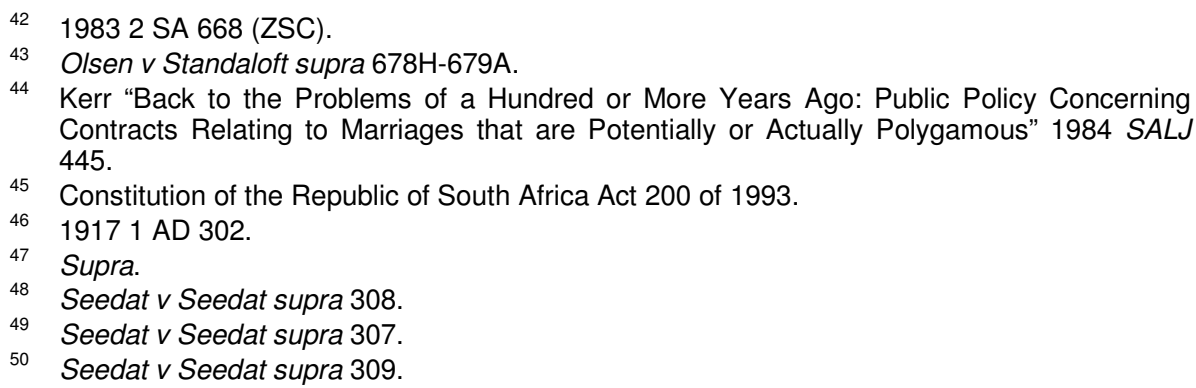


In Ismail $v$ Ismai $^{51}$ the plaintiff, who was married to the defendant by Muslim rites, sued the defendant for the enforcement of certain proprietary consequences arising from their marriage, namely arrear maintenance and deferred dowry. These claims were based on Muslim custom and contract and not on the grounds of recognition of the marriage. The plaintiff also averred that her claims were based on the variable consequences of marriage, and that it is only the invariable consequences that are of relevance to the state. However, the Appellate Division rejected the plaintiff's claims since the marriage was potentially polygamous and did not enjoy ad hoc recognition; it therefore remained contrary to public policy and as such these claims could not give rise to a civil action. ${ }^{52}$

From this case it is apparent that anything contrary to the accepted customs and usages of society was deemed to be contrary to public policy. In Ismail the marriage was denied recognition on the ground of public policy because it violated the principle of equality and not because the potentially polygamous marriage was considered unchristian or immoral. In criticising the above decision, Kaganas and Murray ${ }^{53}$ make the following comment:

"By refusing her claim, the court compounded the inequalities that it identified in Mrs Ismail's marriage. Mr Ismail was home and dry, able to avoid maintenance obligations because the union he entered into treated his wife less favourably than himself. Mrs Ismail was left with the dubious comfort of legal rhetoric proclaiming rights of women. Rather than redressing inequality the case recalls the tensions between different cultural traditions in South Africa and women are caught in the cross-fire".

The decision of the court can be summarized as follows:

- The marriage could not be regarded as a valid civil marriage, because it had not been solemnized by a marriage officer, and was not solemnized in the presence of both parties as prescribed in the Marriage Act. ${ }^{54}$

- Although the legislature had in a number of general statutes, and for a specific purpose recognized polygamous unions (for example, section 21(3) of the Insolvency Act 24 of 1936 describes the word "spouse" to include a wife or husband married "according to any law or custom"), it was done for expediency but was not proof that it expressly or impliedly approved of polygamy.

The decision in Ismail once again confirmed support for the nonrecognition of polygamous unions. The court took the view that the status of civil marriages would be undermined if polygamous unions were recognized.

One of the first cases to be decided in terms of the interim Constitution was that of Kalla $v$ The Master. ${ }^{55}$ The case involved freedom of religion and,

51 Supra.

52 Church "Constitutional Equality and the Position of Women in a Multicultural Society" 1995 CILSA 289.

53 "Law, Women and the Family: The Question of Polygamy in a new South Africa" 1991 Acta Juridica 116119.

54 Kaganas and Murray 1991 Acta Juridica 124.

5519944 BCLR $79(\mathrm{~T})$. 
in particular, the validity of marriages conducted according to Islamic rites. The facts of the case were that in a will executed in 1977 the deceased, who had married his wife by Islamic rites in India in 1948, bequeathed R20 000.00 to her and a further R20 000.00 to a local Mosque. The wife challenged this in court and claimed apportionment of the deceased estate on the ground that she had been married in community of property and further that a universal partnership existed between her and her husband. ${ }^{56}$ The wife contended that the decision of Ismail $v$ Ismail was no longer valid since the constitutional entrenchment of religious freedom for unions concluded under systems of religious law.

The Kalla case raised the question whether section 14(1) of the Constitution of the Republic of South Africa, Act 200 of 1993, which entrenches freedom of conscience, religion, thought, belief and opinion, opened the door to the recognition of hitherto invalid polygamous unions concluded under systems of religious law. ${ }^{57}$ The court disposed of the wife's contentions with the argument that section 241(8) of the interim Constitution precludes the retroactive operation of section 14(1), as the events material to the case occurred before the commencement of the Constitution. The decision of the Master recognizing the marriage as a valid one, was thereby set aside.

The decision that finally broke the long-established pattern of nonrecognition of potentially polygamous marriages that are de facto monogamous, was that of Ryland $v$ Edros. ${ }^{58}$ The importance of this case lies in the fact that it redefines the meaning that has been attributed to the term "public policy" as it was understood in our legal system before 27 April 1994. The case also shows that certain consequences of the marital relationship that were not granted legal recognition because of their potentially polygamous nature, can be enforced. The facts of the case were briefly as follows: The parties were married according to Muslim rites. The plaintiff instituted an action to have the defendant evicted from their matrimonial home. The defendant in return claimed for arrear maintenance, a consolatory gift, and an equitable share on the growth of her husband's estate. The court was not called upon to determine the validity of the marriage or grant recognition to the marriage, but was required to decide whether the claims were based on a contractual agreement between the parties under Islamic law. The issue to be decided was the following:

"Can it be said since the coming into operation of the new Constitution, that a contract concluded by parties which arises from a marriage relationship entered into by them in accordance with rites of their religion and which as a fact is monogamous is contrary to the accepted customs and usages which are regarded as morally binding upon all members of our society or is fundamentally opposed to our principles and institution?"

56 It is interesting to note that the marriage had been recognized by the Department of Home Affairs and so recorded in the population register.

57 Bonthuys "Whither the Validity of Marriages Concluded under a System of Religious Law under the Transitional Constitution" 1995 SA Public Law 200.

$58 \quad 19972$ SA $690(C)$.

59 Ryland $v$ Edros supra 707E-F. 
To reach a decision concerning the issue stated above, Farlam $\mathrm{J}$ relied on provisions as contained in the Preamble of the Constitution, which recognise equality between men and women and people of all races, as well as the equality clause as contained in section 8 of the interim Constitution (presently section 9 of the final Constitution). Having to determine whether the public policy that previously dictated the non-enforcement of consequences of an unrecognized marriage could still preclude it from enforcing such consequences, Farlam $\mathrm{J}$ came to the following conclusion:

"It is quite inimical to all the values of the new South Africa for one group to impose its values on another and that the courts should only brand a contract as offensive to public policy if it is offensive to those values which are shared by the community at large, by all right-thinking people in the community and not only by one section of it. It is clear, in my view, that in the Ismail case the views (or presumed views) of only one group in our plural society were taken into account."

The court held that the ratio in the Ismail case was in conflict with the spirit, purport and objects of the Constitution. If such a conflict occurs, the values underlying Chapter 3 of the Constitution must prevail. The judge further asserted that the values of equality and tolerance of diversity and the recognition of the plural nature of our society are among the values that underlie our Constitution. ${ }^{61}$ Consequently, he held that the Ismail decision no longer operated to preclude a court from enforcing such claims as those brought by the defendant. The essence of the judgment was that the contractual agreements flowing from a marriage, which is potentially polygamous in nature, would not be rendered unenforceable, provided that the terms and obligations emanating from such contracts are not contrary to public policy. It was also held that public policy is essentially a question of fact. Furthermore, public opinion can alter from time to time. It is as though Farlam $\mathrm{J}$ is boldly stating that the "unruly horse" described in the Kader ${ }^{62}$ case, can be tamed and domesticated. This case opens the door for resolving the need to balance multicultural and religious-pluralism in South Africa. ${ }^{63}$ However, despite the progressive decision taken in the Ryland case, the following comments can be made: Firstly, an extensive investigation of polygamy was not conducted as the judgment failed to address the question whether polygamous marriages should be recognized. Secondly, the decision is only applicable to unions which are de facto monogamous. Nevertheless, the decision is to be welcomed as it states that public policy is no longer a vague and arbitrary concept, but that public policy now operates within definitive parameters and is guided by the interpretation of the provisions of section 35(3) of the Constitution, Act 200 of $1993^{64}$

\footnotetext{
Rylands v Edros supra 707G-H.

Palser 1998 Journal for Juridical Science 87.

Supra.

Mahomed "Case Note: Ryland v Edros 19964 All SA 557 (C)" 1997 De Rebus 189.

${ }^{64} S$ 35(3) of the interim Constitution corresponds with s 39(2) of the final Constitution which reads as follows: (2) "When interpreting any legislation, and when developing the common
} 
In Amod v Multilateral Motor Vehicle Accident Fund ${ }^{65}$ the court was once again faced with a challenge to the validity of the decision of the Appellate Division in the case of Ismail $v$ Ismail. ${ }^{66}$ The facts of the case were as follows: The plaintiff was married to Omar Shaik Amod by Islamic rites, and the marriage subsisted for six years until his death in a motor vehicle accident on 25 July 1993. The deceased was the breadwinner of the family and as such supported the applicant throughout marriage. The applicant lodged a claim against the Multilateral Motor Vehicle Accident Fund (hereinafter "the MMF") for compensation for loss of support arising from the death of her husband. It was common cause that the accident was due to the negligence of the other driver.

The issue which arose for consideration was whether the contractual duty of support which a husband owes his wife in terms of their Islamic marriage, satisfied the requirements of a dependant's action for loss of support against a third party. In other words, the question was whether the MMF was liable to compensate Mrs Amod (the plaintiff) for loss of support of the deceased husband to whom she was married according to Islamic rites. The traditional approach in South Africa law that a common law duty of support only arises in respect of either a lawful marriage or a blood relationship, was challenged.

In response to the above traditional legal position, counsel for the plaintiff put forward the following two arguments:

- Public policy has evolved sufficiently since 1982 when Ismail case was decided, and consequently Islamic marriages should, as a matter of public policy, no longer be considered unlawful.

- Alternatively, it was submitted that the court should in terms of section 35(3) of the interim Constitution or section 39(2), read with sections 8(2) and (3) of the 1996 Constitution, develop the common law to recognise a duty of support arising out of an Islamic marriage.

The court a quo dismissed the first argument on the ground that it could not be established on the evidence before the court that a change of public policy had occurred. With regard to the second argument, the court held that there was no provision in the Constitution that indicated that the court was to have legislative powers. The court further held that the intention behind section 8(3)(a) was that if there was a silence in the common law with regard to giving effect to a right in the Bill of Rights, and the legislature did not give effect to such a right, the court must amplify the common law to eliminate such silence. Consequently, it was not the intention of section 8(3)(a) that the court be granted the power to eliminate or alter an existing principle of

law or customary law, every court, tribunal or forum must promote the spirit, purport and objects of the Bill of Rights".

65199712 BCLR 1716 (D)

66 Supra. It was held that a marriage entered into according to Muslim rites was not lawful and that consequently the marriage itself, as well as any contracts or customs flowing from it, was invalid.

67 Clark and Kerr "Dependant's Action for Loss of support: Are Women Married by Islamic Rites Victims of Unfair Discrimination?" 1999 SALJ 20. 
the common law. ${ }^{68}$ This was the task of the legislature. The court was obliged to find that the defendant was not legally liable to compensate the plaintiff for loss of support of her deceased husband, as a legal duty of support only arose out of a lawful marriage.

The matter was taken on appeal directly to the Constitutional Court. The crucial issue which had to be decided by the Constitutional Court was whether the common law should be developed to allow the appellant to claim damages for loss of support. ${ }^{69}$ The application for leave to appeal was dismissed as the Constitutional Court took the view that this question fell primarily within the jurisdiction of the Supreme Court of Appeal. This decision illustrates the reluctance or caution displayed on the part of the courts to apply the Bill of Rights directly to private relationships. ${ }^{70}$

An application for leave to appeal was made to the Supreme Court of Appeal. ${ }^{.1}$ The Supreme Court of Appeal found that the appellant had a good cause of action based on the facts in that firstly, the deceased had a legally enforceable duty to support the appellant; secondly, the duty arose from a solemn marriage in accordance with tenets of recognised and accepted faith; and thirdly, it was a duty which deserved recognition and protection for the purposes of the dependant's action. ${ }^{72}$ Mahomed CJ stated that the correct approach is not to determine whether the marriage was lawful at common law or not, but to enquire whether or not the deceased was under a legal duty to support the appellant during the subsistence of the marriage and, if so, whether the right of the widow was, in the circumstances, a right which deserved protection for the purposes of the defendant's action. ${ }^{73}$ The court based its findings on firstly, an "important shift in the identifiable boni mores of the community" that "must also manifest itself in a corresponding evolution in the relevant parameters of application in this area", ${ }^{74}$ and secondly, on the test laid down in Santam Bpk $v$ Henery. ${ }^{75}$

Jazbhay "Case Notes" 1998 De Rebus 42.

69 Amod v Multilateral Motor Vehicle Accidents Fund 19984 SA 753 (CC).

70 Rautenbach and Du Plessis "The Extension of the Dependant's Action for Loss of Support and the Recogntition of Muslim Marriages: The Saga Continues" 2000 THRHR 302304.

71 Amod v Multilateral Vehicle Accidents Fund (Commission for Gender Equality Intervening) 19994 SA 1319 (SCA).

72 Amod v Multilateral Vehicle Accidents Fund (Commission for Gender Equality Intervening) supra 1331B.

73 Amod v Multilateral vehicle Accidents Fund (Commission for Gender Equality Intervening) supra 1327F.

74 Amod v Multilateral Vehicle Accidents Fund (Commission for Gender Equality Intervening) supra 13291.

7519993 SA 421 (SCA). The test as laid down in Santam $v$ Henery supra $427 \mathrm{H}-\mathrm{J}$ is as follows:

- The claimant for loss of support resulting from the unlawful death of the deceased must establish that the deceased had a duty to support the dependant.

- It had to be a legally enforceable duty.

- The right of the dependant to such support had to be worthy of protection by the law.

- The preceding element had to be determined by the criterion of boni mores. 
The court found that Mrs Amod was owed a legal duty of support arising from her marriage. Accordingly, the MMF was held to be legally liable to compensate the widow for loss of support of her deceased husband. ${ }^{76}$

For the first time, a South African court was prepared to recognize an action for loss of support by a surviving Muslim spouse married in terms of Islamic law. The decision in the Amod case can be heralded as a landmark case regarding the rights of Muslims in South Africa for the following reasons: $:^{71}$

- The insistence of the court that in previous decisions the duty of support which a potentially polygamous, but de facto monogamous marriage, imposed on the husband was not worthy of legal protection, could not be justified. The court held that this was inconsistent with the new ethos of tolerance, pluralism and religious freedom in the present constitutional legal order, and was an untenable basis for the determination of the boni mores of society. ${ }^{78}$

- The court emphasised that its crucial enquiry was whether the relationship between the deceased and the dependant was one which deserved recognition and protection at common law. ${ }^{79}$

- Although the court reached its findings without any reliance on the interpretation clauses of either the interim or final Constitution, Mahomed CJ stated that if the common law is trapped within the limitations of its past, it will lose its legitimacy and effectiveness "in the pursuit of justice among the citizens of a democratic society." ${ }^{80}$ The court based its approach on Roman-Dutch natural law concepts of justice and equality. Mahomed CJ stated that the proper remedy is for the legislature to effect statutory relief for Muslim widows as it did in the case of widows married by African customary law by virtue of the provisions of section 31 of the Book of Laws Amendment Act, 76 of 1963.

Although being heralded as the landmark case regarding the rights of Muslims in South Africa, the effect of the decision in Amod is limited in two ways. Firstly, it is only the claim of a surviving spouse ${ }^{81}$ for loss of support which has been extended to spouses married in terms of unrecognized Muslim law. Muslim marriages have as such not been granted recognition. ${ }^{82}$ Secondly, the court did not deal with polygamous marriages. This can be concluded from the following statement made by Mahomed CJ:

76 Mahomed "Another Landmark Decision in Amod (born Peer) v Multilateral Vehicle Accidents Fund 19994 All SA 421 (A)" 2000 De Rebus 37.

77 Goolam “The 'Potentially Polygamous' Saga: When will it End?” 2000 THRHR 22.

78 Amod v Multilateral Vehicle Accidents Funds (Commission for Gender Equality Intervening) supra $1327 \mathrm{I}-1328 \mathrm{C}$.

79 The approach adopted by Mahomed $\mathrm{CJ}$ is one which will afford welcome and long-overdue relief to Muslim widows.

80 Amod v Multilateral Vehicle Accidents Fund (Commission for Gender Equality Intervening) supra 1330 A.

81 Married in terms of a valid civil marriage.

82 Rautenbach and Du Plessis 313. 
"I have deliberately emphasized in this judgment the de facto monogamous character of the Muslim marriage between the appellant and the deceased in the present matter. I do not thereby wish to be understood as saying that, if the deceased had been party to a plurality of continuing unions, his dependants would necessarily fall in a dependant's action based on a duty which the deceased might have towards such dependants. I prefer to leave that issue entirely open.

It is uncertain whether the court would have followed the same route if the appellant's marriage had been polygamous. ${ }^{84}$

The decision of the Cape Provincial Division in Daniels $v$ Campbell NO ${ }^{85}$ regarding the intestate succession rights of a spouse in a monogamous Muslim marriage further extends the ad hoc legal recognition granted to religious unions. The facts of the case were that the applicant, Juleiga Daniels, had married Mogamat Amien Daniels (the deceased) in accordance with Muslim rites on 2 March 1977. The marriage, which was at all times monogamous, was not solemnized by a marriage officer appointed in terms of the Marriage Act 25 of 1961. No children were born of this marriage. On 27 November 1994, Mogamat Amien Daniels died intestate. The main asset in his deceased estate was a house (hereinafter "the property"). Throughout the marriage until his death, the deceased and the applicant lived on the property.

In terms of the Intestate Succession Act 81 of 1987, the surviving spouse of a deceased person is entitled to inherit from the intestate deceased estate. $^{86}$

In so far as section 2 of the Maintenance of Surviving Spouses Act 27 of 1990 , is concerned, provision is made for the surviving spouse to claim for maintenance against the estate of the deceased spouse where the marriage has been dissolved by death. ${ }^{87}$ However, neither this Act nor the Intestate

83 Amod v Multilateral Vehicle Accidents Fund (Commission for Gender Equality Intervening) supra 1330B-D.

84 Goldblatt "Reviewing the Road Accident Fund" 2000 De Rebus 30.

852004 S SA 331 (CC).

86 The order of intestate succession is set out in detail in section 1 of the Act and provides as follows:

"(1) If after the commencement of this Act a person (hereinafter referred to as the "deceased") dies intestate, either wholly or in part, and

(a) is survived by a spouse, but not by a descendant, such spouse shall inherit the intestate estate;

(b) is survived by a descendant, but not by a spouse, such descendant shall inherit the intestate estate;

(c) is survived by a spouse as well as a descendant

(i) such spouse shall inherit a child's share of the intestate estate or so much of the intestate estate does not exceed in value the amount fixed from time to time by the Minister of Justice by notice in the Gazette [fixed at present at R125 000.00 - see GN 483 in Government Gazette 11188 of 18 March 1988], whichever is the greater; and

(ii) such descendant shall inherit the residue (if any) of the intestate estate."

87 S 2 provides the following:

"(1) If a marriage is dissolved by death after the commencement of this Act the survivor shall have a claim against the estate of the deceased spouse for the provision of his 
Succession Act contains a definition of the word "spouse". The meaning to be attributed to the word "spouse" in each of these Acts, is what lies at the heart of this case. The issues which the court had to determine can be summarized as follows:

- Whether the word "spouse" as utilized in the Intestate Succession Act and the Maintenance of the Surviving Spouses Act could be interpreted to include a person in the position of the applicant, in other words, a husband or wife married in terms of Muslim rites in a de facto monogamous union.

- If the failure to provide for such persons as "spouses" can be regarded as unconstitutional and invalid. If this is the case, can such invalidity be remedied by reading in the provisions proposed by the applicant?

In the determination of the above issues Van Heerden $\mathrm{J}$ stated that it was clear from several judgments of the Constitutional Court that the concept of equality must be understood in a substantive, rather than a formal, sense. This necessarily required an acute awareness of the lived reality of people's lives and an understanding of how real life conditions of individuals and groups have reinforced vulnerability, disadvantage and harm. Furthermore, it was stated that the present interpretation of the word "spouse" does differentiate between de facto monogamous marriages entered into by Muslim rites and marriages entered into in accordance with Christian and Jewish rites and also non-religious (civil) marriages. This differentiation flows from and is limited to the religion, belief and cultural background of persons in the position of the applicant. In other words, being a practising Muslim, the applicant entered into a marriage by Muslim rites. This being a potentially polygynous marriage, it did not comply with the meaning of the term "marriage" underlying the provisions of the Marriage Act. As a result of the cultural practices of the Muslim community within which the applicant lived, the applicant and her husband neglected to have their marriage solemnized by a marriage officer as required in terms of the Marriage Act.

Van Heerden $\mathrm{J}$ stated that it was the interplay between the applicant's religious beliefs and the cultural practices in her community and the fact that South African law has failed to accommodate such beliefs and practices which have caused the applicant to be in her present position properly. ${ }^{88}$

In terms of section $8(2)$ of the interim Constitution religion, belief and culture are all prohibited grounds of discrimination and in terms of section $8(4)$ of the interim Constitution, such differentiation is presumed to constitute unfair discrimination until the contrary is proved. The non-recognition of the applicant as a "spouse" in terms of the relevant Acts, would result in the estate of the deceased to be distributed in a manner which is both inconsistent with Muslim personal law, as well as unfairly discriminate

reasonable maintenance needs until his death or remarriage in so far as he is not able to provide therefore from his own means and earnings."

88 In other words, the applicant's marriage was not recognized as valid in South African law and she did not enjoy the protection afforded to "spouses" by virtue of, inter alia, the Intestate Succession Act and the Maintenance of Surviving Spouses Act. 
against the applicant by ignoring the reality of her de facto monogamous marriage to the deceased.

In view of this, Van Heerden $\mathrm{J}$ concluded that the impugned provisions of the Intestate Succession Act and the Maintenance of Surviving Spouses Act were in breach of the equality clause contained in section 8 of the interim Constitution. In determining the appropriate remedy, the court held that the mere declaration that the challenged provisions are unconstitutional was insufficient. Ancillary relief of "reading into" the challenged provisions wording that will cure the constitutional defect and provide the applicant with meaningful relief, was required. The court therefore made the following order: $^{89}$

1 The omission from section 1(4) of the Intestate Succession Act 81 of 1987, of the following definition was declared to be unconstitutional and invalid: "spouse' shall include a husband or wife married in accordance with Muslim rites in a de facto monogamous union."

2 Section 1(4) of the Intestate Succession Act 81 of 1987, was to be read as though it included the following paragraph after paragraph $(f)$ :

“(g) 'spouse' shall include a husband or wife married in accordance with Muslim rites in a de facto monogamous union."

3 The orders in paragraphs 1 and 2 above would have no effect on the validity of any acts performed in respect of the administration of an intestate estate that has been finally wound up by the date of the order.

4 The omission from the definition of "survivor" in section 1 of the Maintenance of Surviving Spouses Act 27 of 1990, of the words "and includes the surviving husband and wife of a de facto monogamous union solemnized in accordance with Muslim rites" at the end of the existing definition, was declared to be unconstitutional and invalid.

5 The definition of "survivor" in section 1 of the Maintenance of Surviving Spouses Act 27 of 1990, was to be read as if it included the following words after the words

"dissolved by death":

"and includes the surviving husband or wife of a de facto monogamous union solemnized in accordance with Muslim rites."

This landmark decision should be welcomed and should form the basis to alleviate the plight of Muslim women in the same position as the applicant. Many Muslims marry under Islamic law without the marriage being solemnized by a marriage officer as required by the Marriage Act. The conclusion of a marriage without it being solemnized by a marriage officer is in accordance with the tenets of the Islamic religion and culture.

In the recent decision of Hassam $v$ Jacobs $^{90}$ the Cape Provincial Division was faced with the question whether a spouse to a de facto polygamous

Daniels v Campbell NO supra 357

9020084 All SA 350 (CC). 
Muslim marriage was entitled to the benefits as provided to a surviving spouse in terms of the Intestate succession Act 81 of 1987 as well as the Maintenance of Surviving Spouses Act 27 of $1990 .^{91}$ In other words the court was called on to determine whether the decision reached in Daniels $v$ Campbell could be extended to a de facto polygamous Muslim marriage.

The facts of the case were as follows: The applicant and the deceased entered into a marriage in accordance with Muslim rites on the 3 December 1972. The parties continued to live together as husband and wife until the deceased's death on 22 August 2001. Prior to the deceased's death he entered into a second marriage with the third respondent, also in terms of Muslim rites in 2000.

The primary issue in this matter was what a widow's portion in terms of the Intestate Secession Act is and whether the surviving spouses to a de facto polygamous Muslim Marriage had a claim for reasonable maintenance in terms of the Maintenance of Surviving Spouses Act.

The court held that in defining the term "spouse" in a manner which is consistent with the foundational constitutional values of human dignity, equality and freedom, there was no justification not to apply the equitable principles underlying the Intestate Succession Act and the Maintenance of Surviving Spouse Act to Muslim widows in a de facto polygamous Muslim Marriage. ${ }^{92}$ There was therefore no justification for excluding the widower of a polygamous Muslim Marriage from the provisions of the Intestate Succession Act or the Maintenance of Surviving Spouses Act. Furthermore, the continued exclusion of the windows of polygamous Muslim marriages from the benefits of these two Acts would be unfairly discriminatory against them and would amount to a violation of their religion, culture as well as the infringement of their right to dignity. With regard to the issue as to whether widows of polygamous Muslim marriages are included in the definition of the term "survivor" (as used in the Maintenance of Surviving Spouse Act and "spouse" as used as the Intestate Succession Act) these terms in fact included a surviving spouse to a polygamous Muslim marriage.

Furthermore, the court held that section 1(4)(f) of the Intestate Secession Act was inconsistent with the Constitution on the basis marital status, religion, culture as well as the right to dignity as it only made provision for a spouse in a de facto monogamous Muslim marriage to be an heir in the estate of her deceased husband. Section 1(4)(f) of the Intestate Succession Act now has to be read so as to include all the widows of the de facto polygynous Muslim marriage.

In Hassam $v$ Jacobs NO (Muslim Youth Movement of South Africa and Women's Legal Trust as Amici Curiae) ${ }^{93}$ an application was made for

91 Baker "Toepassing van Islamitiese Reg in Suid-Afrika: Hassam v Jacobs 20084 All SA 350 (C)" 2008 Obiter 533540.

92 In Daniels $v$ Campbell NO it was stated in par 22 and 23 that the purpose of these two Acts is to provide relief to a particularly vulnerable section of society namely, widows with a view to obviating their bereavement being compounded by dependence and possible homelessness.

93 CCT 83\08 [2009] ZACC 19. 
confirmation of the decision of the Western Cape High Court which declared section 1(4)(f) of the Intestate Succession Act (the Act) to be inconsistent with the Constitution as it makes provision for only one spouse in a Muslim Marriage to be an heir.

In the confirmation proceedings before the Constitutional Court the following issues were identified for consideration, namely: ${ }^{94}$

"(a) Does the exclusion of the spouses in polygynous Muslim marriages from the intestate succession regime as established by the Intestate Succession Act violate section 9(3) of the Constitution? In particular:

i Does the exclusion constitute discrimination?

ii If so, does it constitute unfair discrimination?

iii If so, is this unfair discrimination justifiable under section 36 of the Constitution?

(b) If this exclusion violates section 9(3) of the Constitution, can the word "spouse" in the Intestate Succession Act be read to include spouses in polygynous Muslim marriages?

(c) If such an interpretation is not possible, what is the appropriate relief?"

In addressing the first issue Nkabinde $\mathrm{J}$ found that the Intestate Succession Act does differentiate between widows married in terms of the Marriage Act 25 of 1961 and those married in terms of Muslim rites; between widows in monogamous Muslim marriages and those in polygynous Muslim marriages; and between polygynous customary marriages and those in polygynous Muslim marriages. The differentiation and exclusion of spouses in polygynous Muslim marriages was found not to pass constitutional muster as the rights to equality before the law and equal protection of the law are foundational. Furthermore the court held that this differentiation amounts to discrimination as the failure to grant widows of polygynous Muslim marriages the benefits of the Act will result in these widows being caused significant and material disadvantages which the equality provision expressly wishes to avoid. The plight of widows in a monogamous Muslim marriage has since the decision in the Daniels case, been improved as they are now recognized as spouses under the Act. Widows in polygynous Muslim marriages, however, still suffer the effects of non-recognition and as such the differentiation between the spouses in a monogamous Muslim marriage and those in a polygynous Muslim marriage amounts to unfair discrimination. Nkabinde $\mathrm{J}$ held that it would be constitutionally unacceptable and unjust to grant a widow of a monogamous Muslim marriage the protection offered by the Act and to deny the same protection to widows of a polgynous Muslim marriage. The exclusion of women in the position of the applicant from the protection on the Act therefore unfairly discriminates against them on the grounds of religion, marital status and gender. The exclusion and unfair discrimination could not be justified under section 36 of the Constitution. In other words, this exclusion could not be justified in a society which is guided by principles of equality, fairness, equity, social progress, justice, human dignity and freedom.

94 Hassam v Jacobs NO (Muslim Youth Movement of South Africa and Women's Legal Trust as Amici Curiae) supra par 20. 
With regard to the second issue the court held that the word "spouse" as it appears in the Act does not include more than one partner to a marriage and consequently section 1 of the Act must be read as though the words "or spouses" appear after the word "spouse" wherever it appears in section 1 of the Act. In the formulation of the appropriate remedy Nkabinde referred to section 172(1) of the Constitution which requires a court, when deciding a constitutional matter within its power, to declare that any law that is inconsistent with the Constitution is invalid to the extent of it inconsistency. Section 172(1) furthermore requires the court to make any order that is just and equitable, including an order limiting the retrospective effect of the declaration of validity for any period and on any conditions to allow the competent authority to correct the defect. It was therefore held that as the word "spouse" in the Act is not reasonably capable of being understood to include more than one spouse in the context of a polygynous union in order to remedy the defect, the words "or spouses" are to be read-in after each use of the word "spouse" in the Act. It was held that the declaration of invalidity should operate retrospectively with effect from 27 April 1994 except that it does not invalidate any transfer of ownership prior to the date of this order of any property pursuant to the distribution of the residue of an estate, unless it is established that, when the transfer was effected, the transferee was on notice that the property in question was subject to a legal challenge on the grounds upon which the applicant brought the present application.

The Constitutional Court confirmed the decision of the Western Cape High Court that women who are party to a polygynous Muslim marriage concluded under Muslim personal law are spouses for the purpose of inheriting in terms of the Intestate Succession Act or claiming from estates of the deceased in terms of the Maintenance of Surviving Spouses Act.

From the above discussion it is evident that prior to the advent of the present constitutional era, the South African courts, apart from certain statutory exceptions, consistently refused to recognize and give effect to Muslim marriages because they were potentially polygamous and therefore regarded as being contrary to public policy. After the enactment of the interim constitution in 1993 and the final constitution in 1996, the founding values of the Constitution took precedence and the courts, although not granting full recognition to Muslim marriages, were prepared to grant ad hoc recognition to the consequences that flowed from Muslim marriages. It is submitted that the two landmark decisions in the Daniels and Hassam cases should form the basis to alleviate the plight of Muslim women in the same position as the applicants. Both these decisions are an indication of the potential impact of the constitutional value of equality in South African family law, as is apparent from the discussion that follows. 


\section{THE CONSTITUTION AND ITS EFFECT ON THE STATUS AND CONSEQUENCES OF MUSLIM MARRIAGES}

\section{Freedom of religion, conscience, thought, belief and opinion}

In terms of section $15(1)^{95}$ of the Constitution everyone has the right to freedom of conscience, religion, thought, belief and opinion. Included in the right to religious freedom is the right to hold religious beliefs, to propagate religious doctrine and to manifest religious belief in worship and practice. ${ }^{96}$ Section 15(1) appears to grant to those who wish to be married under Customary, Hindu, Jewish or Muslim law the freedom to do so because it involves a decision based on conscience, thought, belief and opinion, and in the case of Muslim, Hindu and Jewish law, it also involves a decision based on religion.

Despite the fact that marriages can be entered into in accordance with Muslim rites, such marriages and the consequences flowing from such marriages do not enjoy the same protection which is accorded to civil marriages. This seems to be contrary to the provisions of section 15 , as although section 15 does not deny the state from recognising or supporting religion, it does require the state to treat all religions equally. The state is required to act fairly and equitably in its dealings with the various religions in South Africa. Although the Constitution allows the state to support religious observances, it is not permitted to act inequitably. ${ }^{97}$ The Constitution does not allow the explicit endorsement of one religion over others, as this would amount to a threat to the free exercise of religion and when governmental prestige, power and financial support is placed behind a particular religious belief, the result is that religious minorities are indirectly forced to conform to the religion officially approved by the government. ${ }^{98}$ The Constitution requires the legislature to refrain from favouring one religion over others. Fairness and even-handedness in relation to diverse religions are necessary components of freedom of religion. ${ }^{99}$

In this respect Sachs $J$ in the case of $S v$ Lawrence; $S v$ Negal; $S v$ Solberg ${ }^{100}$ commented as follows:

"The Constitution, then, is very much about the acknowledgement by the state of different belief systems and their accommodation within a non-hierarchical framework of equality and non-discrimination. It follows that the state does not take sides on questions of religion. It does not impose beliefs, grant privilege to impose advantages on adherents of any particular beliefs, require

\footnotetext{
The Constitution of the Republic of South Africa, 1996.

Smith "Freedom of Religion under the final Constitution" 1997 SALJ 217.

$S$ v Lawrence; S v Negal; S v Solberg 19974 SA 1176 (CC) 1217A.

Ibid.

S v Lawrence; S v Negal; S v Solberg supra 1218B-C.

100 Supra 1226B-C.
} 
conformity in matters simply of belief, involve itself in purely religious controversies, or marginalise people who have different beliefs."

As South Africans are in general deeply religious people and because religion touches the profoundest and most delicate emotions of people, it is a matter which has to be addressed with infinite circumspection, sensitivity and tolerance. ${ }^{101}$

Furthermore, in section 15(3)(a) it is stated that the section does not prevent legislation recognizing (i) marriages concluded under any tradition or a system of religious, personal or family; or (ii) systems of personal and family law under any tradition, or adhered to by any persons professing a particular religion; and secondly, recognition in terms of paragraph (a) must be consistent with section 15 and other provisions of the Constitution.

Section 15(3) indicates that while recognition of religious legal systems or polygamous marriages concluded according to religious rites would be granted legal recognition, such recognition must be consistent with the Bill of Rights and other provisions of the Constitution. ${ }^{103}$ The provision that section 15(3)(a) must be consistent with the other provisions of the Constitution, is bound to create conflict. Goolam ${ }^{104}$ states the following with regard to this conflict:

"The reason for this is that the Bill of Rights is individual-centred, based on Western ideas while Islamic law, like African law, has as its underlying principle the idea of communitarianism. The fundamental question which needs to be answered, therefore is: Why should Western ideas and philosophy serve as the yardstick, particularly in South Africa, an African country? A further crucial question is: Why should a legal system such as Islam, based as it is on divine revelation, play second fiddle to a secular, human legal system?"

Religious-based marriages, giving effect to personal and family law, are often considered to discriminate against women ${ }^{105}$ on the grounds of gender

101 Devenish A Commentary on the South African Constitution (1998) 56.

102 In interpreting section 15 reference must be to the interpretation clause, section 39, which provides:

"(1) When interpreting the Bill of Rights, a court, tribunal or forum -

(a) must promote the values that underlie an open and democratic society based on human dignity, equality and freedom;

(b) must consider international law; and

(c) may consider foreign law.

(2) When interpreting any legislation, and when developing the common law or customary law, every court, tribunal or forum must promote the spirit, purport and objects of the Bill of Rights.

(3) The Bill of Rights does not deny the existence of any other rights or freedoms that are recognized or conferred by common law, customary law or legislation, to the extent that they are consistent with the Bill."

103 Currie and De Waal The Bill of Rights Handbook (2005) 355.

104 Rautenbach and Goolam Introduction to legal pluralism in South Africa Part II Religious Legal Systems (2002) 120.

$105 \mathrm{Eg}$, polygamy is seen as discriminatory against women; in Jewish and Muslim law it is easier for men to divorce women than for women to divorce men. 
and sexual orientation. This discrimination should be permissible in so far as it is required by the tenets of the religion. ${ }^{106}$

It is also submitted that polygamy should not be singled out as the predominant characteristic of religious marriages currently not enjoying legal recognition. The institution of marriages performed under religious rites should rather be looked at holistically so as to determine whether indeed there is discrimination against women and whether such marriages do in fact violate gender equality. It is further submitted that if marriages performed under religious rites are not granted legal recognition, this will merely compound the inequalities presently experienced by women in a polygamous marriage and those who are not in such a relationship, as well as between the various women married to the same man.

\section{The right to culture}

In sections 30 of the final Constitution and 31(1)(a) of the interim Constitution it is stated that "everyone has the right to participate in the cultural life of their choice" and "to enjoy their culture, practice their religion and use their language." The deduction which can be drawn from both these sections, is that potentially polygamous marriages should be granted legal recognition and protection if they involve marrying according to one's culture. Culture plays a very important role in the lives of Muslims to the extent that the Islamic legal position has become part of the local Islamic culture, and therefore to be a practising Muslim, one would enter into a marriage by Muslim rites, according to the tenets of Islam which would usually involve the cultural practices of the Muslim community. Islam does not differentiate between religion, law and morals. However, mention must be made of the fact that both these sections are subject to the general provision that they should not be in conflict with any other provision as contained in the Bill of Rights. An illustration of the effect of the general provision mentioned above is provided by the case of Christian Education SA v Minister of Education. ${ }^{107}$ In this case the applicant, an association representing 196 independent Christian schools, challenged the constitutionality of section 10 of the South African Schools Act, 84 of 1996, which prohibited the administration of corporal punishment. The applicant contended that it constituted a violation of religious and cultural freedom, since corporal punishment of children was a vital part of the Christian religion. ${ }^{108}$ The High Court held that the applicant had not shown that the belief in corporal punishment was a sincerely held religious belief, nor that the prohibition constituted a substantial burden on the freedom of religion of the association's members, since other forms of punishment and correction of children that were acceptable to the members of the association were not prohibited by the South African Schools Act. ${ }^{109}$ With regard to the argument that the prohibition was a violation of the right to

\footnotetext{
Currie and De Waal 340.

19999 BCLR 951 (SE)

Currie and De Waal 635.

10984 of 1996.
} 
practice a religion in community with others in terms of section 31(1), the court held that because corporal punishment was an infringement of the right to dignity and freedom from degrading punishment ${ }^{110}$ contained in the Bill of Rights,

"to allow corporal punishment to be administered at Applicant's schools, even if it is done in the exercise of the religious beliefs or culture of those involved, would be to allow the applicant's members to practice (sic) their religion or culture in a manner inconsistent with the Bill of Rights in contravention of $s$ $31(2)$ of the Constitution."

The matter was taken on appeal to the Constitutional Court. ${ }^{12}$ The Constitutional Court declined to decide whether the prohibition of corporal punishment was a violation of section 31 or whether corporal punishment was a practice inconsistent with the Bill of Rights for purposes of section $31(2)$. However, the court made the following remark with regard to section 31(2):

"Section 31(2) ensures that the concept of rights of members of communities that associate on the basis of language, culture and religion, cannot be used to shield practices which offend the Bill of Rights. These explicit qualifications may be seen as serving a double purpose. The first is to prevent protected associational rights of members of communities from being used to 'privatize' constitutionally offensive group practices and thereby immunise them from external legislative regulation or judicial control. This would be particularly important in relation to practices previously associated with the abuse of the notion of pluralism to achieve exclusivity, privilege and domination. The second relates to oppressive features of internal relationships primarily within the communities concerned, where section 8 , which regulates the horizontal application of the Bill of Rights, might be specially relevant."

\section{The right to human dignity}

Section 10 of the final Constitution states that "everyone has inherent dignity and the right to have their dignity respected and protected". 14 The protection of human dignity is inherent in the protection of virtually all other rights, to the extent that it can be regarded as a pre-eminent value in the Constitution, even more so than the right to life. ${ }^{115}$ The right to human dignity is a core constitutional right. All rights contained in the Bill of Rights must be interpreted to promote the Constitution's ambition of creating an "open and democratic society based on human dignity, equality and freedom". ${ }^{116}$ In describing the right to human dignity and the right to life as the most important human rights, the Constitutional Court in $S \vee$ Makwanyane ${ }^{117}$ stated the following:

\footnotetext{
S 10 of the Constitution of the Republic of South Africa, 1996.

1 Christian Education South Africa v Minister of Education supra 1999 965B-C.

2 Christian Education South Africa v Minister of Education 20004 SA 757 (CC).

13 Christian Education South Africa v Minister of Education supra 2000 774A-C.

$114 \mathrm{~S} 10$ of the final Constitution corresponds with $\mathrm{s} 10$ of the interim Constitution.

115 Devenish (1998) 51.

116 S 39 of the Constitution of the Republic of South Africa, 1996.

11719953 SA 391 (CC) par 144.
} 
"Recognizing a right to dignity is an acknowledgement of the intrinsic worth of human beings: human beings are entitled to be treated as worthy of respect and concern. This right therefore is the foundation of many of the other rights that are specifically entrenched in ... [the Bill of Rights]."

"The rights to life and dignity are the most important of all human rights, and the source of all other personal rights in the Bill of Rights. By committing ourselves to a society founded on the recognition of human rights we are required to value these two rights above all others."

Human dignity is not only an enforceable right which must be respected and protected, it is also a value that informs the interpretation of possibly all other fundamental rights and it is further of central importance in the limitation enquiry in terms of section 36 of the Constitution. ${ }^{120}$ In respect of marriage and family life, Van Heerden J held in Dawood, Shalabi, Thomas $v$ Minister of Home Affairs ${ }^{121}$ that the right to dignity must be interpreted to afford legal protection to the institutions of marriage and family life, such protection extending at the very least to the core elements of these institutions, namely, the right and duty of spouses to live together as spouses in community of life. ${ }^{122}$

The approach as expounded by Van Heerden $\mathrm{J}$ above was confirmed by the Constitutional Court, ${ }^{123}$ where O'Regan $\mathrm{J}$ held that the Constitutional Court indeed protected the rights of persons to marry freely and to raise a family. ${ }^{124}$

In this respect, the Constitutional Court elaborated as follows:

"The decision to enter into a marriage relationship and to sustain such a relationship is a matter of defining significance for many, if not most, people and to prohibit the establishment of such a relationship impairs the ability of the individual to achieve personal fulfilment in an aspect of life that is of central significance. In my view, such legislation would clearly constitute an infringement of the right of dignity. It is not only legislation that prohibits the right to form a marriage relationship that will constitute an infringement of the right of dignity, but any legislation that significantly impairs the ability of spouses to honour their obligations to one another would also limit that right. A central aspect of marriage is cohabitation, the right (and duty) to live together, and legislation that significantly impairs the ability of spouses to honour that obligation would also constitute a limitation of the right to dignity."

From the discussion above it could be taken to indicate that potentially polygamous marriages should be recognized so as to uphold the dignity of persons who marry outside of the civil law. However, if it could be shown that such marriages are prejudicial to women and therefore violate their dignity, it may not be afforded recognition. ${ }^{126}$

18 S v Makwanyane supra par 328

119 S v Makwanyane supra par 144.

120 Currie and De Waal 278.

20001 SA 997 (C).

122 Currie and De Waal 278

123 Dawood v Minister of Home Affairs 20003 SA 936 (CC).

124 Dawood v Minister of Home Affairs supra par 28.

125 Dawood v Minister of Home Affairs supra par 37.

126 Palser 1998 Journal for Juridical Science 89. 
The two positions as set out above necessarily warrant a discussion on equality as set out in section 8 of the interim, and section 9 of the final Constitution, in order to determine whether or not the dignity of women is indeed violated by polygamous unions.

\section{The right to equality}

In the discussion of the right to equality, the following aspects will be addressed: Firstly, the meaning of equality; secondly, the distinction between formal and substantive equality; thirdly, the Constitutional Court's analysis of the equality clause; and lastly, the notion of equality versus religious family laws.

\section{The meaning of equality}

\section{Introduction}

Before commencing on a discussion of the meaning of equality, it must be borne in mind that a constitution, especially in the context of South Africa, is a document which reflects the hopes and fears of the nation at a specific moment between its misfortunes of the past and its aspirations for the future. ${ }^{127}$ This is evidenced by the statement made by Mahomed $\mathrm{J}$ in $S \mathrm{~V}$ Achedon: ${ }^{128}$

"The Constitution of a nation is not simply a statute which mechanically defines the structures of government and the relations between the government and the governed. It is 'a mirror reflecting the national soul', the identification of the ideals and aspirations of a nation; the articulation of the values bonding its people and disciplining its government. The spirit and the tenor of the constitution must therefore preside and permeate the processes of judicial interpretation and judicial discretion."

As a result of this, the provisions of a constitution may sometimes be stated in an idealistic and abstract manner. Owing to the need to convey a clear message about the separation between the old and the new dispensations and because the constitution must be seen to encapsulate the values of the new dispensation, it has been accepted that a constitution has to be interpreted generously.

In this respect, Mahomed $\mathrm{J}$ made the following statement in $S \mathrm{v}$ Makwanyane: ${ }^{30}$

"In some countries the Constitution only formalizes, in a legal instrument, a historical consensus of values and aspirations evolved incrementally from a stable and unbroken past to accommodate the needs of the future. The South African Constitution is different: it retains from the past only what is defensible and represents a decisive break from, and a ringing rejection of, that part of

127 Dlamini "Equality or Justice? Section 9 of the Constitution Revisited - Part 12002 Journal for Judicial Science 1417.

12819912 SA $805(\mathrm{Nm}) 813$.

129 Dlamini 2002 Journal for Judicial Science 17.

130 Supra par 262. 
the past which is disgracefully racist, authoritarian, insular, and repressive, and a vigorous identification of and commitment to a democratic, universalistic, caring and inspirationally egalitarian ethos expressly articulated in the Constitution. The contrast between the past which it repudiates and the future to which it seeks to commit the nation is stark and dramatic."

A discussion of the meaning of equality will now be considered. In section 9(1) the final Constitution stipulates that everyone is equal before the law and has the right of equal protection and benefit of the law. The Constitution further defines equality as including "the full and equal enjoyment of all rights and freedoms". ${ }^{13}$ To promote the attainment of equality, provision is made for legislative and other measures designed to protect or advance persons, or categories of persons, disadvantaged by unfair discrimination. ${ }^{132}$ The Constitution furthermore prohibits the state, as well as any individual, from unfairly discriminating directly or indirectly against anyone on one or more grounds, including race, gender, sex, pregnancy, marital status, ethnic, or social origin, colour, sexual orientation, age, disability, religion, conscience, belief, culture, language and birth. ${ }^{133}$ For this reason the Constitution stipulates that national legislation must be enacted to prevent or prohibit such unfair discrimination. ${ }^{14}$ Discrimination under one of the grounds listed under section $9(3)$ is presumed to be unfair, unless it is proved that the discrimination is fair. ${ }^{15}$

The aim of section 9 is to create an egalitarian society where justice and fairness prevail and where all people are treated as human beings with dignity and self-worth. The question which now arises is what this equality guarantee in terms of section 9 means. The approach as adopted by the Constitutional Court will be considered.

\section{Non-discrimination as the core element of equality}

The Constitutional Court has situated the anti-discrimination principle firmly at the heart of its approach to equality. ${ }^{136}$ For a claimant to succeed with an

\footnotetext{
S 9(2) of the Constitution of the Republic of South Africa, 1996.

Ibid.

133 S 9(3) of the Constitution of the Republic of South Africa, 1996.

134 S 9(4) of the Constitution of the Republic of South Africa, 1996; and see, eg, The Promotion of Equality and Prevention of Unfair Discrimination Act 4 of 2000.

135 S 9(5) of the Constitution of the Republic of South Africa, 1996.

136 The Constitutional Court has dealt with equality in a substantive manner in the following cases: Brink v Kitshoff NO 19966 BCLR 752 (CC); 19964 SA 197 (CC); Prinsloo v Van der Linde 19976 BCLR 759 (CC); 19973 SA 1012 (CC); President of the Republic of South Africa v Hugo 19976 BCLR 708 (CC); 19974 SA 1 (CC); Harksen v Lane NO 199711 BCLR 1489 (CC); 19981 SA 300 (CC); Larbi-Odam v MEC for Education (North West Province) 199712 BCLR 1655 (CC); 19981 SA 745 (CC); Pretoria City Council v Walker 19983 BCLR 257 (CC); 19982 SA 363 (CC); and The National Coalition for Gay and Lesbian Equality v Minister of Justice 199812 BCLR 1517 (CC). All, but the last of these cases actually dealt with $\mathrm{s} 8$ of the interim Constitution, but when it finally had the opportunity to deal with equality in terms in $s 9$ of the 1996 Constitution in The National Coalition for Gay and Lesbian Equality v Minister of Justice supra the court proceeded on the assumption that "the equality jurisprudence and analysis developed by this Court in relation to section 8 of the interim Constitution is applicable equally to section 9 of the 1996
} 
equality challenge, it will therefore almost always be necessary to frame the matter as one of "unfair discrimination" and not in terms of a general claim to equality. ${ }^{137}$ The approach of the Constitutional Court to view the guarantee of equality in section 9 as little more than a guarantee of non-discrimination, in effect means that the manner in which the court determines whether an impugned provision constitutes unfair discrimination, becomes extremely important. In The National Coalition for Gay and Lesbian Equality v Minister of Justice ${ }^{138}$ the Constitutional Court justified its approach with reference to the text of section 9 , as well as with reference to policy considerations. The court listed these policy considerations as the following: ${ }^{139}$

- institutional aptness;

- functional effectiveness;

- technical discipline;

- historical congruency;

- compatibility with international practice; and

- conceptual sensitivity.

Sachs $\mathrm{J}$ elaborated on these policy considerations with the following statement: ${ }^{140}$

"By developing its equality jurisprudence around the concept of unfair discrimination this court engages in a structured discourse centred on respect for human rights and non-discrimination. It reduces the danger of overintrusive judicial intervention in matters of broad social policy, while emphasizing the court's special responsibility for protecting fundamental rights in an affirmative manner. It also diminishes the possibility of the court being inundated by unmeritorious claims, and best enables the court to focus on its special vocation, to use the techniques for which it has a special aptitude, and to defend the interests for which it has a particular responsibility. Finally, it places the court's jurisprudence in the context of evolving human rights concepts throughout the world, and of our country's own special history."

Being mindful of criticism of the concept of equality as being labeled as "empty", "complex" and "elusive", ${ }^{141}$ the Constitutional Court has made a conscious decision to focus its equality jurisprudence on the concept of nondiscrimination. In the words of Devenish: ${ }^{12}$

"It is regrettable that of all the noble principles of democratic philosophy, equality has proved the most intractable to convert from merely an ideal to the hard world of reality."

Constitution, notwithstanding certain differences in the wording of these provisions" (1530F par 15).

137 De Vos "Equality for All? A Critical Analysis of the Equality Jurisprudence of the Constitutional Court" 2000 THRHR 64.

138 Supra 1530-1533 par 15-19.

139 The National Coalition for Gay and Lesbian Equality $v$ The Minister of Justice supra 15711572 par 123.

140 lbid.

141 Fagan "Dignity and Unfair Discrimination: A Value Misplaced and a Right Misunderstood" 1998 SAJHR 220.

142 Devenish A Commentary on the South African Constitution (2000) 36. 


\section{The centrality of human dignity}

The Constitutional Court has furthermore adopted the approach that at its core the equality guarantee protects individuals' "human dignity". ${ }^{14}$ The centrality of human dignity for equality jurisprudence was first established in President of Republic of South Africa v Hugo, ${ }^{144}$ where Goldstone J made the following remark: ${ }^{145}$

"The prohibition on unfair discrimination in the interim Constitution seeks not only to avoid discrimination against people who are members of disadvantaged groups. It seeks more than that. At the heart of the prohibition of unfair discrimination lies a recognition that the purpose of our new constitutional and democratic order is the establishment of a society in which all human beings will be accorded equal dignity and respect regardless of their membership of particular groups."

The court placed human dignity at the heart of its equality enquiry. The court furthermore provided a broad and expansive definition of human dignity as it stated that human dignity will be impaired wherever a legally relevant differentiation treats people as "second-class" citizens or "demeans them" or "treats them as less capable for no good reason", or otherwise offends "fundamental human dignity" or where it violates an individual's selfesteem and personal integrity.

The view of equality as inextricably linked to the concept of human dignity, has been reiterated in subsequent Constitutional Court judgments ${ }^{147}$ and has further been elaborated on in Prinsloo $v$ Van der Linde. ${ }^{148}$ The court gave an expansive interpretation of what constitutes discriminatory treatment by adding that not only an infringement of human dignity, but also "other forms of differentiation, which in some other way affect persons adversely in a comparably serious manner"149 could constitute a harm prohibited by the non-discrimination provisions of the Constitution. ${ }^{150}$ The concept of human dignity as used by the court appears to be closely linked to the idea that all human beings have an equal moral worth, regardless of differences between them. Where this equal moral worth is denied by legal provisions, the court will find that there has been an impairment of "fundamental human dignity" or that the complainant has been adversely affected in a comparably serious

143 De Vos 2000 THRHR 65.

144 Supra.

145 President of Republic of South Africa v Hugo supra 728H-729B.

146 Albertyn and Goldblatt "Facing the Challenge of Transformation: Difficulties in the Development of an Indigenous Jurisprudence of Equality" 1998 SAJHR 248260.

147 President of the Republic of South Africa $v$ Hugo supra par 41; Harksen $v$ Lane supra par 50.

148 Supra.

149 Prinsloo v Van der Linde supra 773E-774B. See also Harksen v Lane supra 1511G-H: "Whether or not there is discrimination will depend on whether, objectively, the ground is based on attributes and characteristics which have the potential to impair the fundamental human dignity of persons as human beings or to affect them adversely in a comparably serious manner."

150 De Vos 2000 THRHR 66. 
manner. ${ }^{151}$ From the discussion above, it can be concluded that the concept of "fundamental human dignity" should act as a guiding factor to capture the idea of humans as equally capable and deserving of concern, respect and consideration. ${ }^{152}$

\section{Formal and substantive equality}

\section{Introduction}

As the apartheid social and legal system was squarely based on inequality and discrimination, the right of equality is very important to the new postapartheid constitutional order. In Brink v Kitshoff $N^{153}$ the Constitutional Court stated the following:

"Apartheid systematically discriminated against black people in all aspects of social life. Black people were prevented from becoming owners of property or even residing in areas classified as 'white', which constituted nearly $90 \%$ of the land mass of South Africa; senior jobs and access to established schools and universities were denied to them; civic amenities, including transport systems, public parks, libraries and many shops were also closed to black people. Instead, separate and inferior facilities were provided. The deep scars of this appalling programme are still visible in our society."

The effects of decades of systematic racial discrimination are evident in all the key measures of equality of life in South Africa. Numerous examples can be cited as indicative of the above, namely: ${ }^{154}$

- White South Africans are significantly healthier and better nourished than their black fellow citizens;

- white South Africans enjoy relatively high standards of literacy and education; ${ }^{155}$

- infant mortality rates and life expectancy among black South Africans are equivalent to those of the poorest nations of the world; and

- wealth and poverty are notoriously unequally distributed.

Consequently, as a result of the legacy of inequality from the past, the constitutional commitment to equality cannot simply be understood as a commitment to formal equality. Several judgments delivered by the Constitutional Court have indicated that the Constitution guarantees substantive equality. The right to equality must also be interpreted and applied purposively and contextually, with due regard to impact and

151 De Vos 2000 THRHR 66.

152 This formulation was first used by the Canadian Supreme Court in Andrews $v$ Law Society of British Columbia (1989) 1 SCR 143 171: "The promotion of equality entails the promotion of a society in which all are secure in the knowledge that they are recognized as human beings deserving of concern, respect, and consideration."

153 Supra par 40 (O’ Regan J).

154 Currie and De Waal 231.

155 According to a 1999 survey, of the approximately 2.8 million South Africans above the age of 20 who had received no education at all, 2.6 million were African. See Statistics South Africa October Household Survey (1999). 
disadvantage so that the values underlying the Constitution are promoted. ${ }^{156}$ It is therefore not sufficient to remove the racist laws from the books and to ensure that similar laws cannot be enacted in future, as this will result in formal equality and not substantive equality as envisaged by the Constitution.

\section{Defining formal and substantive equality}

Formal equality means sameness of treatment: the law must treat individuals in the same manner regardless of the circumstances within which they find themselves. ${ }^{157}$ As formal equality is blind to entrenched, structural inequality, it completely ignores actual social and economic disparities between individuals and groups. A reliance on formal equality may actually exacerbate inequality, as equality has to address actual conditions of human life and not an abstract concept of identical treatment, which is equally applicable to all. ${ }^{158}$ It is for this reason that the Constitutional Court has delivered several judgments in which it has indicated that equality must be understood substantively, and not formally. ${ }^{159}$ The Constitutional Court has explicitly rejected the traditional, liberal conception of equality based on the notion of sameness and similar treatment.

In contrast to formal equality, substantive equality examines the actual social and economic conditions of individuals and groups in order to determine whether the Constitution's commitment to equality is being upheld. Substantive equality accepts the reality of the present injustice, caused by past discrimination. As a result, those individuals or groups who were discriminated against in the past and are presently as a result disadvantaged, are now entitled to preferential or advantaged treatment so that real equality for all will ultimately emerge in society in the future. ${ }^{160}$ In other words, the law should recognize the unequal life chances occasioned by race, gender, socio-economic status and a host of other factors, which affect a person's ability to compete on an equal footing.

The following example will demonstrate the differences between formal and substantive equality, as these two approaches to the equality might yield very different outcomes in practice.

The provision of benefits to employees is usually linked to length of service. The social responsibility born by women for raising children inevitably results in an interruption of their employment. The result is that women generally do not achieve the necessary length of service to qualify

\footnotetext{
156 Albertyn and Goldblatt "The Decriminalization of Gay Sexual Offences: National Coalition of Gay and Lesbian Equality v The Minister of Justice 19986 BCLR 726 (W)" 1999 SAJHR 461462.

157 Albertyn and Kentridge "Introducing the Right to Equality in the Interim Constitution" 1994 SAJHR 149153.

158 De Vos 2000 THRHR 67

159 President of the Republic of South Africa v Hugo supra 129G; Brink v Kitshoff NO supra $768 \mathrm{G}$ and National Coalition for Gay and Lesbian Equality $v$ Minister of Justice supra $1565 \mathrm{H}-1566 \mathrm{~A}$.

160 This is expressly provided for in s 9(2) which is an affirmative action provision.
} 
for benefits. A formal application of equality would not find this to be an instance of gender discrimination because the social context, which causes the inequality, and would not be taken into account. Substantive inequality, on the other hand, would take into account the implications of women's child-rearing roles and would consequently find that a rule that links benefits to the length of service, discriminates against women.

It is for these reasons that the Constitutional Court has aligned itself into an understanding of equality which seeks to address and remedy material inequalities. In President of Republic of South Africa $v$ Hugo $^{161}$ the Constitutional Court stated the following:

"We need to develop a concept of unfair discrimination which recognises that
although a society which affords each human being equal treatment on the
basis of equal worth and freedom is our goal, we cannot achieve that goal by
insisting upon identical treatment in all circumstances before that goal is
achieved. This view is already clear in the court's endorsement of 'human
dignity' at the heart of equality jurisprudence, since it is based on the notion
that all individuals have equal moral worth, not that all individuals are actually
born free and equal. Each case, therefore, will require a careful and thorough
understanding of the impact of the discriminatory action upon the particular
people concerned to determine whether its overall impact is one which
furthers the constitutional goal of equality or not. A classification, which is
unfair in one context, may not necessarily be unfair in a different context."

In the National Coalition for Gay and Lesbian Equality case Sachs J once again confirmed that equality should be interpreted contextually: ${ }^{162}$

"Human rights are better approached and defended in an integrated rather than a disparate fashion. The rights must fit the people, not the people the rights. This requires looking at rights and their violations from a personcentred rather than a formula-based position, and analyzing them contextually rather than abstractly."

In elaborating further on the Constitutional Court's substantive approach to equality, Ackermann $\mathrm{J}$ stated that:

"[i]t is insufficient for the constitution merely to ensure, through its Bill of Rights, that statutory provisions, which have caused such unfair discrimination in the past are eliminated. Past unfair discrimination frequently has ongoing negative consequences, the continuation of which is not halted immediately when the initial causes thereof are eliminated, and unless remedied, may continue for a substantial time and even indefinitely. Like justice, equality delayed is equality denied."

In Brink $v$ Kitshoff NO, ${ }^{164}$ where the Constitutional Court was called upon to deal with an alleged breach of the right to equality, it indicated that the context in which equality must be judged is formed, firstly, by the constitutional text in its entirety and, secondly, by the country's recent

\footnotetext{
161 Supra 729G-H.

162 The National Coalition for Gay and Lesbian Equality v Minister of Justice supra $1565 \mathrm{H}$ 1566A.

163 The National Coalition for Gay and Lesbian Equality v Minister of Justice supra 1546 par 60.

164 Supra.
} 
history. ${ }^{165}$ Therefore, any consideration of whether a legally relevant differentiation actually constitutes a breach of section 9 , will first have to take into account the history of the group or groups to which the complainant belongs. Where such provisions contribute to the creation or perpetuation of patterns of group disadvantage for groups disfavoured in the past or groups that continue to be disfavoured in society, it will be very difficult for the court to find the measures constitutional. However, where the legally relevant differentiation is aimed not at the creation or perpetuation of patterns of group disadvantage, but instead is aimed at breaking down those structural inequalities and thus at reaching for "true" or "substantive" equality, the court will be reluctant to declare the measures unconstitutional. ${ }^{166}$

Therefore, the court's approach requires a contextual approach, the ongoing structural inequality in society may be taken into account when deciding on the fairness of the discrimination.

\section{The Constitutional Court's analysis of section 9}

In order to develop the interpretation approach to equality in a substantive and contextual manner, the Constitutional Court set out the "equality test" in Harksen $v$ Lane NO. ${ }^{168}$ The test reads as follows:

“(a) Does the provision differentiate between people or categories of people? If so, does the differentiation bear a rational connection to a legitimate government purpose? If it does not, then there is a violation of section $9(1)$. Even if it does bear a rational connection, it might nevertheless amount to unfair discrimination under section 9(3). To determine whether the differentiation amounts to unfair discrimination, a two-stage analysis needs to be made.

(b) (i) Where the differentiation complained of is based on one or more of the sixteen grounds specified in section 9(3), for example race, sexual orientation and marital status, it will be presumed for the purposes of section $9(5)$ that 'unfair discrimination' has been sufficiently proved until the contrary is established. If not based on a specific ground, the differentiation must not still amount to discrimination if objectively viewed it is based on attributes and characteristics which have the potential to impair the fundamental dignity of persons as human beings or to affect them.

(ii) If the differentiation does amount to 'discrimination', the question which needs to be asked is whether such discrimination is unfair. If it has been found to have been on a specified ground, then unfairness will be presumed. If it occurs on an unspecified ground, then unfairness will have to be established by the complainant. The test for unfairness focuses mainly on what impact the discrimination had had on the complainant and others in his or her situation.

(c) If the discrimination is found to be unfair, then one has to determine whether such discrimination can be justified under the limitation clause in terms of section 36 . This entails showing that the criteria as set out in

165 Of particular significance was the systematic discrimination suffered by black people under apartheid. Systematic patterns of discrimination on grounds other than race may have caused, and may continue to cause considerable harm. See Brink $v$ Kitshoff supra $768 \mathrm{H}-\mathrm{J}$.

166 Brink v Kitshoff NO supra 769C.

167 De Vos 2000 THRHR 68.

168 Supra 1511E-J. 
section 36 are satisfied, namely: the right has been limited by law of general application for reasons that can be considered reasonable and justifiable in an open and democratic society based on human dignity, equality and freedom."

Despite the equality test set out in Harksen $v$ Lane NO it must be borne in mind that the equality provision does not prevent the government from classifications and from treating some people different to others, provided that such differentiation does not amount to unfair differentiation. In Prinsloo $v$ Van der Linde ${ }^{169}$ the court was called on to determine the validity of section 84 of the Forest Act 22 of 1984, which established fire control areas where schemes of compulsory fire control were created. Owners of land situated outside the designated compulsory fire control areas were not required to embark on fire control measures, but they were encouraged to do so by means of a presumption of negligence by the landowner in respect of fires occurring in "non-controlled areas". The court held that although the Act differentiated between owners of land in fire control areas and non-fire control areas, this did not amount to unfair discrimination as it was rationally connected to the legitimate government purpose of preventing veld fires. ${ }^{170}$

From the above discussion it can be deduced that an understanding of the contextual analysis within transformative equality jurisprudence entails locating the impugned Act within real life conditions and understanding both disadvantages and harm. This, in effect, means that the following has to be done, namely:

- The socio-economic conditions of the individuals and group concerned must be examined;

- the impact of the impugned provision on social patterns and systematic forms of disadvantage must be identified;

- the complex and compound nature of group disadvantage and privilege must be understood by looking at grounds of discrimination in an intersectional manner; and

- the historical context of the case must be fully appreciated and explored. ${ }^{171}$

\section{Equality versus religious family laws}

Equality is relevant for the discussion in casu in the following ways:

- Persons who enter into Muslim marriages should be treated equally in comparison to those who enter into marriages according to South African civil law.

- In contrast, however, potentially polygamous marriages can be regarded as being discriminatory against women on the grounds of sex and gender.

169 Supra.

170 See also Jooste v Score Trading (Pty) Ltd 19989 BCLR 1106 (E); Pretoria City Council v Walker 19982 SA 363 (CC); 19983 BCLR 257 (CC).

171 Albertyn and Goldblatt 1998 SAJHR 263. 
In other words, potentially polygamous marriages may offend against the principle of gender and the prohibition of discrimination based on sex.

As discussed previously, Muslim marriages have been denied recognition on the ground that they are potentially polygamous. In Ismail $v$ Ismail $^{172}$ Muslim marriages were denied recognition on the ground that they violated the principle of equality in two respects: firstly, the bride is not present at the ceremony; ${ }^{173}$ and secondly, it is more difficult for women than men to obtain a divorce. ${ }^{174}$ Kaganas and Murray ${ }^{175}$ argue that possibly the equality issue was invoked in Ismail merely to provide a new rationalization for old prejudices.

Despite the fact that customary law can similarly be shown to be in conflict with section 9 in terms of its patriarchal structure, recognition was granted to customary marriages in terms of the Recognition of Customary Marriages Act. ${ }^{176}$ The South African Law Commission (SALC) in its report on customary marriages ${ }^{177}$ stated that the principles of equality and nondiscrimination are of particular reference as traditionally the issue of the constitutionality of the recognition of customary marriages boils down to a conflict between the constitutional values of culture and gender equality. An argument advanced for the recognition of customary marriages was that sections 9(3) and (4) of the final Constitution enshrine the right not to be unfairly discriminated against on the basis of culture. Furthermore, section 30 affords everyone the right to participate in the cultural life of his/her choice, and section 31(1) provides that persons belonging to a cultural community may not be denied the right to enjoy their culture. ${ }^{1}$

Clearly, customary law is part of culture. As such, it was argued that customary marriages should be recognized as it formed part of the culture of the indigenous population of South Africa. ${ }^{179}$ The problem faced by the SALC was that certain elements of the culture of indigenous law seemingly discriminated against women. The fundamental question facing the SALC was whether in a constitutional dispensation which upholds equality and non-discrimination, it would be appropriate to grant legal recognition to a marriage which allows polygny. The fact that only men were allowed more than one wife, and women cannot have more than one husband, was regarded as being incompatible with the equality clause as contained in section 9 of the final Constitution. The result is that there is no formal equality in polygamy. Dlamini ${ }^{180}$ argues that the mere fact that polygny permits the man to have more than one wife, does not necessarily mean that

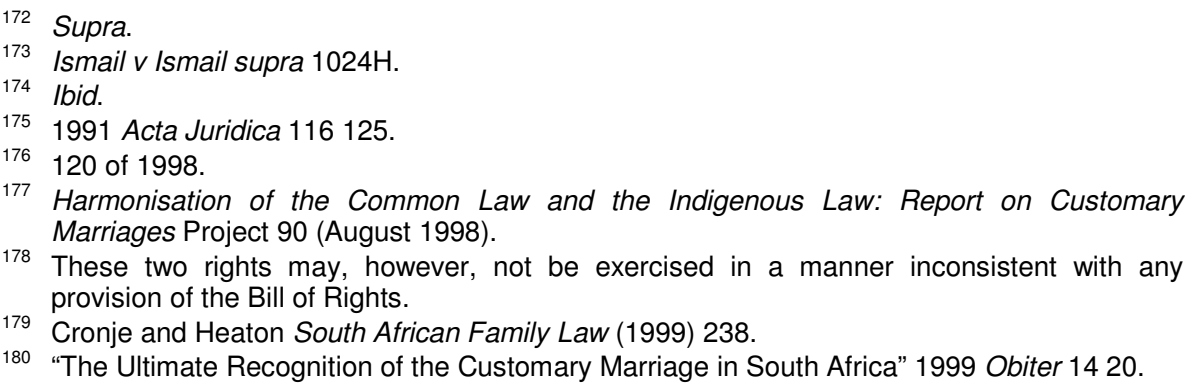


women would want to have more than one husband or that it would necessarily be in the interests of women to have more than one husband as this would impose an impossible burden on a woman. Dlamini furthermore submits that it should not be assumed that polygamy holds no benefits for women, as it provides a valuable social function. Examples of benefits which polygamy might offer can be listed as the following: ${ }^{181}$

- sharing of domestic and farm work;

- companionship;

- the reduction of sexual demands on each wife;

- promotion of independence through freeing wives to engage in economic activities and to join self-help groups;

- reduction of the divorce rate;

- women who might otherwise remain unmarried are legally absorbed into a domestic unit; and

- a man who might be tempted to commit adultery and thereby risk the breakdown of his marriage, may instead contract another valid union. ${ }^{182}$

In deciding whether the recognition of a customary marriage is inconsistent with the Constitution, the SALC stated that in deciding whether a legal rule or institution constitutes an infringement of the constitutional right to equality, often leads to a balancing of interests which necessarily entails a consideration of broader social, political and economic issues. In this regard, the argument that polygny prejudices women had to be weighed against the claim that it performed valuable social functions. ${ }^{183}$ The SALC submitted that while the Constitution upholds non-discrimination, it also provides for the recognition of cultural rights and that the customary marriage forms part of the African culture, to which black people have a right. The SALC also submitted that if recognition of customary law is to be something more than an empty gesture towards the African cultural tradition, the Bill of Rights must be construed in a manner that a set of western values does not become dominant, merely due to the fact that customary law is different. ${ }^{184}$ Despite the fact that the present constitutional dispensation is largely based on western values, it was submitted that this did not mean that African values should be completely discarded. The final Constitution should be regarded as an honest attempt to merge both western and African values. The SALC also commented that judging from the emerging constitutional jurisprudence ${ }^{185}$ on issues of culture, customary law and religion, the courts

181 Cronje and Heaton (1999) 239.

182 Dlamini 1999 Obiter 21. Dlamini argues that polygny is aimed at protecting women in the sense that all women are regarded as the man's wife and therefore they have a certain legal status whereas a mistress has no right or status emanating from the relationship.

183 South African Law Commission Report on Customary Marriages (1998) 87.

184 South African Law Commission Report on Customary Marriages (1998) 24. Eg, in the former Transvaal, polygny and lobolo were deemed to be "uncivilized". As a result, the courts bastardized almost the entire native population, depriving practically every native father of guardianship or other rights to his children

185 Eg, Mthembu v Letsela 20003 SA 867 (SCA) 
are not prepared to strike down a customary practice merely because it is controversial or is under attack from various interest groups. ${ }^{186}$

Based on its findings, the SALC made the recommendation that customary marriages should be granted legal recognition and that customary marriages should continue to be potentially polygamous. The most important reasons for making this recommendation, was that it would be difficult to enforce a prohibition of polygamy, and that polygamy appears to be obsolescent.

The recommendations of the SALC culminated in the enactment of the Recognition of Customary Marriages Act 120 of 1998. In terms of section $2(1)$ of the Act, a marriage which is entered into before the coming into operation of the said Act, is valid only if it complies with the customary law requirements for a valid marriage.

In terms of section 3(1), a customary marriage concluded after the coming into operation of the said Act, will be valid if the prospective spouses both are above the age of 18 and both consent to the marriage, and the marriage is negotiated and entered into or celebrated in accordance with customary law. From this it is clear that provided the requirements for a valid customary marriage as set out in sections 2(1) and 3(1) are met, full recognition is granted to customary marriages. Before the Recognition of Customary Marriage Act, customary marriages were also regarded as being invalid because they permit polygamy. As in Muslim marriages, this rule applied irrespective of whether or not the husband had in fact taken more than one wife or envisages taking more than one wife. Despite the fact that customary marriages are custom based, and not religion based, and that there exist larger numbers of customary marriages than Muslim marriages, granting recognition to customary marriages and not to Muslim marriages, is tantamount to discrimination.

Polygamy could discriminate against women and cause inequality as Muslim law only allows polygamy. ${ }^{187}$ In Muslim law the wife is not afforded the liberty of taking another husband. However, it should be pointed out that women who do enter into potentially polygamous marriages are not forced to do so, as consent on the part of both parties to the marriage is required.

It may also be argued that Muslim marriages offend against the principle of equality in that: ${ }^{188}$

- The husband determines the composition of the family;

- women bear the responsibility for the children, yet have no rights over them;

- the husbands are often unable to give sufficient money and attention to all their wives; and

186 South African Law Commission Report on Customary Marriages (1998) 91.

187 Polygny refers to the practice of a husband having more than one wife. Polyandry refers to the practice of a wife having more than one husband. Polygamy simply means a plurality of husbands or wives.

188 Roodt 1995 Codicillus 57. 
- women are allowed to be dominated, sexually stereotyped and treated as property.

Having stated the above, it should be borne in mind that monogamy is also no guarantee for equality, and that the treatment of women as property, gender stereotyping and domination are issues not limited to polygyny.

South Africa has committed itself to gender equality on both a national and international level. This is evident from the following:

- On 29 January 1993 South Africa ratified the United Nation's Convention on the Elimination of All Forms of Discrimination Against Women, 1979 (CEDAW).

Article 15 of the Convention obliges state parties to ensure equality of men and women before the law and in civil matters. Article 16(1)(h) obliges state parties to take appropriate measures to ensure that spouses have the same rights of "ownership, acquisition, management, administration, enjoyment and disposition of property".

Section 39(1)(b) of the 1996 Constitution provides that international law must be considered when a court interprets the Bill of Rights. It is clear that the Convention must be taken into consideration when a dispute concerns discrimination against women. The provisions of the Convention could have a definite effect on the interpretation and application of any law relating to gender equality in South Africa.

- In February 2000 the Promotion of Equality and Prevention of Unfair Discrimination Act, 4 of 2000, (PEPUDA) was passed. The purpose of the Act 15 is two-fold, namely to promote equality and to prevent unfair discrimination. In terms of section 1(viii) discrimination is defined as any act or omission which directly or indirectly withholds benefits, opportunities or advantages from any person on one or more grounds of the prohibited grounds. Equality includes in terms of section 1 (ix) de jure and de facto equality and also equality in terms of outcomes. The said Act applies to vertical and horizontal relationships and enjoys supremacy over all other Acts except the 1996 Constitution, amending Acts of parliament and the Employment Equity Act, 55 of 1998.

- In terms of section 187 of the 1996 Constitution, a Commission for Gender Equality must be established. The duty of the Commission is to protect and promote respect for gender equality.

- Gender equality is recognized as both a value and a fundamental right in terms of sections 1(1); 7(1), 9, 36(1) and 39(1) of the 1996 Constitution.

Despite South Africa's commitment to gender equality on a national and international level, it is submitted that the failure to grant recognition to potentially polygamous marriages on the ground of gender equality, means that the plight of these women is actually worsened in that they are left 
without effective legal protection should such a union be dissolved either by death or divorce. ${ }^{189}$

It is clear from the above discussion that the South African legal approach to potentially polygamous marriages is in urgent need of reform, in the light of the democratization process and the enactment of the Constitution. As a result of the need for laws to be exacted to deal with the heterogeneity of South African society, the South African Law Commission (SALC) was entrusted with the task of investigating the possible recognition of Muslim personal law in South Africa. In May 2002, the SALC published its findings in Project 59 on Islamic Marriages and Related Matters.

The following proposals were made by the SALC:

- Couples contemplating a marriage should have the right to choose a marital system which is compatible with their religious beliefs and with the Constitution. This implies that the marriage could, by way of contract, be governed by Muslim personal law, or by secular law.

- To the extent that legislation is to give effect to the recognition of Islamic marriages, the new statute should provide for both new marriages and existing marriages.

- In the case of new marriages, the legislation should provide for the following matters:

- the age of consent should be 18 years;

- actual and informed consent to the conclusion of a marriage in written form;

- the designation of marriage officers who are entitled to perform Islamic marriages;

- the registration of marriages by the signing of a marriage register;

- the formalities pertaining to the time, place and manner of solemnization of Islamic marriages;

- the appropriate marriage formula for the solemnization of an Islamic marriage;

- a prohibition on marriages within certain prohibited degrees of relationship, including the rules relating to fosterage according to Muslim personal law;

- a standard contractual provision in terms of which a Muslim personal law system is established in the event of parties contemplating a Muslim marriage;

- the prescription of penalties for false representations or statements.

- In the case of existing marriages, such marriages would require registration upon satisfactory proof to a designated marriage officer that there is an existing Islamic marriage.

189 In Ismail $v$ Ismail supra the court compounded inequalities that it had identified. 
- Regarding the registration of existing Islamic marriages, the parties must reach an agreement as to the appropriate matrimonial property regime.

- Regarding divorce and the potentially contentious issue of a marriage by talaq, it is submitted that there are compelling reasons of public policy to preclude the dissolution of marriages save on the type of grounds contemplated in the Divorce Act 70 of 1979. It is suggested that marriage officers should be required to recognize a talaq in the presence of the parties and that for record and official purposes and for consonance with the Constitution, a talaq should be confirmed by a court before it takes effect.

- In order to deal with constitutional concerns, any proposed legislation stipulating the grounds on which the conclusion of a polygamous marriage would be permissible, has to be narrowly circumscribed in recognition of the limitations set out by the Quraan itself.

- As wives and children frequently require special protection to ensure their continued welfare upon the dissolution of a marriage, protective measures similar to those in the Divorce Act 79 of 1979, and the Recognition of Customary Marriages Act 120 of 1998, should be included in the statute giving recognition to Muslim personal law.

The SALC correctly suggested that any proposed legislation stipulating the grounds on which the conclusion of a polygamous marriage would be permissible, had to be narrowly circumscribed in recognition of the limitations set out by the Qur'an itself. ${ }^{190}$ It has been submitted that in any intended legislation, a court must be vested with the discretion either to grant or to deny permission to contract a second marriage. Furthermore, despite the fact that section 7(6)-(9) of the Recognition of Customary Marriages Act merely requires a court to approve a written contract regulating the future matrimonial property system of the marriage where the man wishes to take a further wife it is submitted that in the case of Muslim marriages where an application for approval is made to the court where the man wishes to take a further wife, the court must satisfy itself that the husband is able to maintain equality between his spouses as is prescribed by the Qur'an. In other words, the conditions under which a man may enter into a further marital union with another woman, has to be set out satisfactorily.

On 22 July 2003 a draft Bill proposing the recognition of Muslim marriages was released. The aims of the draft Bill can be listed as follows:

- To make provision for the recognition of Muslim marriages;

- to specify the requirements for a valid Muslim marriage;

- to regulate the registration of Muslim marriages;

- to recognize the status and capacity of spouses in Muslim marriages;

190 Doi Ar Shariah : The Islamic Law (1948) 147. It must be appreciated that polygamy is only permissible in extraordinary circumstances. There must be inexorable reasons for polygamy and the wives must be treated with absolute impartiality. 
- to regulate the proprietary consequences of Muslim marriages;

- to regulate the termination of Muslim marriages and the consequences thereof; and

- to provide for the making of regulations and to provide for matters connected therewith.

Despite the release of the draft Bill in 2003 it has been left unattended since then. As a result of the failure to table the draft Bill since its release in 2003, the Woman's Legal Centre on the 20 May 2009 brought an application for direct access to the Constitutional Court, ${ }^{191}$ seeking an order to force the President and Parliament to enact a law recognizing Muslim marriages. The applicant averred that the President and Parliament had failed to discharge their constitutional obligations of protection by not enacting a law that makes provision for the recognition of Muslim marriages. The applicant therefore sought an order that the Constitutional Court direct the President and Parliament to fulfill these obligations within eighteen months by "preparing, initiating, enacting and implementing an Act of Parliament providing for the recognition of all Muslim marriages as valid marriages for all purposes in South Africa and regulating the consequences of such recognition." ${ }^{192}$ The issues for consideration were firstly whether the obligations contended for by the applicant were within the meaning of section $167(4)(e)^{193}$ of the Constitution and secondly, if it was not, whether it were appropriate in all the circumstances for the Constitutional Court to be the court of the first and last instance in the application for direct access under section 167(6)(a)..$^{194}$

The court in dealing with these two issues narrowed its arguments to that of jurisdiction and did not deal with any part of the substantive relief claimed nor did it consider whether Parliament or the President may be under an obligation to enact legislation to recognize Muslim Marriages. The court dismissed the application on the basis that the application in its present form was misconceived as it was directed solely to the Constitutional Court and sought to engage the court's exclusive jurisdiction, by-passing other courts with constitutional jurisdiction. The court further held that the power to grant litigants direct access outside the court's exclusive competence is one that is rarely exercised by the court, and with good reason. The reasons being, that if it were to act as a first and last instance, it would deprive all parties to a dispute of a right to appeal and the court would also deprive itself of the benefit of the other courts' insights. Despite dismissing the application for direct access, the court emphasized that the outcome of the present application does not reflect on the substance of the claim that the President

191 Women's Legal Centre Trust v President of the Republic of South Africa (with the United Ulama Council of South Africa as Amici Curiae) [2009] ZACC 20.

192 Women's Legal Centre Trust $v$ President of the Republic of South Africa (with the United Ulama Council of South Africa as Amici Curiae) supra par 1.

193 S 167(4)(e) provides that only the Constitutional Court may decide that Parliament or the President has failed to fulfill a constitutional duty.

$194 \mathrm{~S}$ 167(6)(a) provides that national legislation or the rules of the Constitutional Court must allow a person, when it is in interests of justice and with leave of the Constitutional Court to bring a matter directly to the Constitutional Court. 
and Parliament are under a duty to enact legislation recognizing Muslim marriages.

\section{CONCLUSION}

The Constitution of the Republic of South African, 1996, makes provision for legislation recognizing marriages or systems of personal and family law under Muslim personal law. ${ }^{195}$ It is furthermore evident from the discussion of various cases, ${ }^{196}$ that public policy is now more tolerant towards Muslim marriages according to Islamic rites. Seen in this light, Muslim marriages should be afforded legal recognition. The failure to enact legislation providing for the recognition of all Muslim marriages as valid marriages as well as regulating the consequences of such recognition can be regarded as breaches of the right to equality, the right to dignity, the right to freedom of conscience, religion, thought, belief and opinion, the right to participate in the cultural life of one's choice and the right to enjoy and practise religion. It is submitted it has become imperative that legislation be enacted to recognize and regulate Muslim marriages as parties to, and the children born of Muslim marriages, suffer from piecemeal adjudication of the issues relating to nonrecognition of Muslim marriages. Furthermore, many of the affected parties married in terms of Muslin rites do not have access to legal advice or the resources to litigate through the courts. In the absence of such legislation, Muslims, especially Muslim women, have to endure many hardships and challenges, because, in the absence of a legal framework for the regulation of Muslim marriages and divorce, the married lives of Muslims remain unpredictable and outside their control. The recognition of Customary Marriages Act 120 of 1998 implicitly makes provision for polygamy amongst Black South Africans. The Act recognizes customary marriages where a person is a spouse in more than one customary marriage and where the marriage was concluded either before or after the enactment of the said Act. For the sake of consistency, the recognition of potentially polygamous Muslim marriages requires the enactment of a statute equivalent to that of the Recognition of Customary Marriages Act and the Civil Union Act 17 of 2006.

195 S 15(3) of the Constitution of the Republic of South Africa, 1996.

196 Ryland v Edros supra; Amod v Multilateral Vehicle Accidents Fund (Commission for Gender Equality Intervening), Daniels v Campbell supra; Hassam v Jacobs supra; and Hassam v Jacobs NO (Muslim Youth Movement of South Africa and Women's Legal Trust as Amici Curiae supra. 